\title{
PCR-based detection of EGFR, ALK, KRAS and BRAF mutations in Russian patients with lung adenocarcinoma: a single-center experience
}

\author{
N. V. MITIUSHKINA ${ }^{1, *}$, M. M. KHOLMATOV ${ }^{1,2}$, A. R. VENINA ${ }^{1}$, V. I. TIURIN ${ }^{1}$, G. A. YANUS ${ }^{1,2}$, T. N. SOKOLOVA ${ }^{1}$, O. S. YATSUK ${ }^{1}$, O. A. ZAITSEVA ${ }^{1}$, \\ A. O. IVANTSOV ${ }^{1,2}$, E. SH. KULIGINA ${ }^{1}$, A. V. TOGO ${ }^{1,2}$, E. N. IMYANITOV ${ }^{1,2,3,4}$ \\ ${ }^{1}$ N. N. Petrov Institute of Oncology, Saint Petersburg, Russia; ${ }^{2}$ St Petersburg Pediatric Medical University, Saint Petersburg, Russia; ${ }^{3}$ I. I. Mech- \\ nikov North-Western Medical University, Saint Petersburg, Russia; ${ }^{4}$ St Petersburg State University, Saint Petersburg, Russia
}

${ }^{*}$ Correspondence: nmmail@inbox.ru

Received December 25, 2017 / Accepted April 11, 2018

\begin{abstract}
In contrast to other countries with predominantly white populations, Russian smoking-related lung cancers (LC) are mainly squamous cell carcinomas and approximately half lung adenocarcinomas (AdCa) are not related to tobacco consumption. Given that smoking significantly influences the probability of presence of actionable mutations in LC, one would expect that Russian lung AdCa patients would differ from other white populations in distribution of EGFR, ALK, KRAS and BRAF mutations. Herein, 2,336 consecutive lung AdCa cases, including 1,203 patients with known smoking status, were subjected to sequential testing for the above mutations. One quarter of lung AdCa patients carried either EGFR or ALK mutation with combined prevalence of $42 \%$ in those who had never smoked but only $8 \%$ in smokers. There was only a moderate difference in KRAS mutation frequency between ever- and never-smokers in EGFR/ALK-negative cases (31\% vs. $23 \%$ ), and this was mainly attributed to increased prevalence of G12C substitution in the former group. The occurrence of BRAF V600E mutation was $1.7 \%$ and $4 \%$ in EGFR/ALK/KRAS mutation-negative ever- and never-smokers, respectively. ALK testing of 470 EGFR-mutated tumors revealed only $1(0.2 \%)$ instance of translocation. Similarly, KRAS testing identified 1 (1.25\%) mutation in 80 EGFR-mutated AdCa and none in 48 ALK-rearranged AdCa. Therefore, concurrent actionable mutations in lung adenocarcinoma are exceptionally rare and sequential gene testing can be regarded as a reliable option.
\end{abstract}

Key words: lung adenocarcinoma, EGFR, ALK, KRAS, BRAF

The development of targeted therapies has provided crucial progress in the treatment of patients with lung adenocarcinoma (AdCa). A substantial portion of AdCa is caused by actionable mutations in the EGFR gene which sensitise the tumor to EGFR tyrosine kinase inhibitors [1-3]. ALK translocations are associated with pronounced tumor response to crizotinib, ceritinib and alectinib [4]. KRAS mutated proteins are not pharmaceutically targeted in clinical settings, but a subset of KRAS-associated lung cancers (LC) respond to inhibition of the MEK, a downstream member of the KRAS signaling cascade [5-7]. Importantly, intensive search for more effective therapies for this specific category of cancers is currently underway (https://www.cancer.gov/research/key-initiatives/ras). The inhibitors of mutated BRAF, either alone or in combination with MEK inhibitors, are active against the LC carrying BRAF V600E mutation [8-10]. In addition, some lung AdCa carry activated ROS1, RET, HER2 and MET kinases which can also be efficiently down-regulated by available targeted drugs [11-14].

Multigene testing for LC remains complicated because the majority of patients are diagnosed at an inoperable stage, so the tumor material is in tiny biopsies. In addition, the distribution of actionable mutations strongly depends on patient race, smoking, gender, age and country of residence. For example, lung adenocarcinomas in Russia appear to be significantly distinct from other countries with predominantly white populations. AdCa histology is a prevailing LC type in Europe and America, and the majority of AdCa diagnosed in these regions are related to tobacco smoke. In contrast, smoking-related cancers in Russia are usually squamous cell because of previous popularity of high-tar cigarettes. Accordingly, up to half of Russian lung AdCa is seen in never-smokers, and Russian AdCa patients demonstrate approximately twice higher rate of the EGFR mutations and ALK translocations compared to Western countries [15, 
16]. These findings cause expectation that the distribution of other actionable genetic lesions has characteristic features, and this study therefore analyses the pattern of common somatic mutations in various Russian AdCa patient categories.

\section{Patients and methods}

This study considered all consecutive patients with lung AdCa referred to the N.N. Petrov Institute of Oncology for molecular genetic analysis from November 2013 to July 2016. Patients provided written informed consent. Nucleic acids were extracted from FFPE tissue using the TRIzol reagent (Invitrogen), and RNA was subjected to reverse transcription by RevertAid Reverse Transcriptase (Thermo Fisher Scientific) in the presence of random hexamers in accordance with the manufacturer's recommendations. The molecular tests were performed in a sequential manner (Figure 1), given that the driver mutations are mutually exclusive in most instances $[17,18]$. All PCR primer sequences, reaction conditions and pictures illustrating positive and negative tests results are provided in the Supplementary Methods file.

EGFR mutations (exon 19 deletions and L858R point mutation) were detected as described in our earlier report [19], and the EGFR wild-type tumors were further subjected to analysis of ALK translocations using the two-step procedure: samples were screened for unbalanced expression of the 5'/3'-ends of the ALK transcript [20] and those with evidence of ALK rearrangement were subsequently genotyped for 18 known ALK fusion variants. The EGFR/ALK mutationnegative lung AdCa were further screened for the presence of KRAS mutations in codons 12-13, 61 and 146; high-resolution melting (HRM) analysis was used in the prescreening and allele-specific PCR and/or direct sequencing identified the type of mutation [21]. Similarly, combined allele-specific PCR for V600E substitution and HRM/sequencing for identification of rare exon 15 mutations were used for BRAF gene analysis [21]. Sanger sequencing was conducted with the GenomeLab GeXP Genetic Analysis System (Beckman Coulter) and PyroMark Q24 instrument (Quiagen) was used for pyrosequencing. In addition to sequential gene testing, we performed a separate study to evaluate the probability of concurrent occurrence of EGFR, ALK and KRAS mutations. Statistical analysis was done with R software (https://www.rproject.org/).

\section{Results}

Lung AdCa patient characteristics are presented in Table 1. Patterns of EGFR and ALK mutations in Russian patients

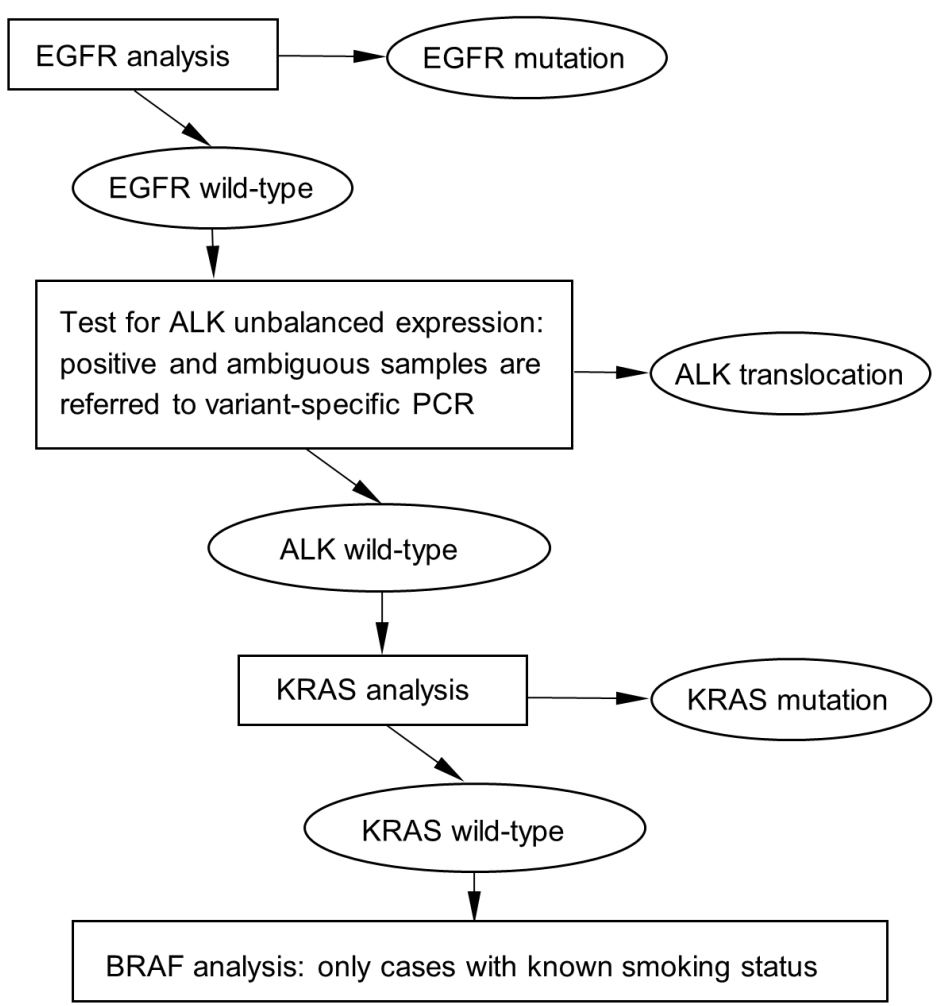

Figure 1. Genotyping workflow. Sequential genetic testing was implemented throughout this study: EGFR-mutations were studied first followed by the analysis of ALK, KRAS and BRAF genes. 
with lung AdCa were already described in our previous reports $[15,16]$. The EGFR and ALK mutations in this dataset agree with our previous results of being more prevalent in women and non-smokers (Table 2, Supplementary Table S1). In addition, ALK gene fusions were associated with younger patient age (median age was 55 years in ALK-positive group vs 61 years in the ALK-negative group, Mann-Whitney U test $\mathrm{p}$-value $\left.=2.53 \times 10^{-8}\right)($ Supplementary Table S2).

KRAS mutations were detected in 394/1,370 (29\%) patients, who lacked actionable lesions in EGFR and ALK kinases. KRAS substitutions were only slightly more common in smokers $(31 \%)$ than in non-smokers $(23 \%)$.

The distribution of particular KRAS mutations subtypes strongly depended on smoking history (Table 3). Transversions were characteristic for smokers ( $29 \%$ vs $17.8 \%$, Fisher's exact test $\mathrm{p}$-value $\left.=2.6 \times 10^{-4}\right)$, and this was entirely attributed to G12C (GGT>TGT) exchange because the prevalence of non-G12C transversions did not depend on a history of tobacco exposure (Table 4). G12C (GGT>TGT) mutations occurred significantly more often in male than in female non-smokers and these mutations were associated with older

Table 1. Characteristics of patients with lung adenocarcinoma.

\begin{tabular}{lcccc}
\hline & Ever-smokers & Never-smokers & Smoking status unknown & All \\
\hline Number & 613 & 590 & 1133 & 2336 \\
Gender (\% females) & $9.1 \%$ & $78.1 \%$ & $39.4 \%$ & $41.2 \%$ \\
Age: median (range) & $61(30-86)$ & $63(26-85)$ & $62(23-88)$ & $62(23-88)$ \\
\hline
\end{tabular}

Table 2. Main genotyping results and comparison between 'ever- and never'-smokers.

\begin{tabular}{|c|c|c|c|c|c|}
\hline & Ever-smokers & Never-smokers & $\begin{array}{l}\text { Smoking status } \\
\text { unknown }\end{array}$ & All & $\begin{array}{c}\text { Ever-smokers vs never-smokers, } \\
\text { chi-square test }\end{array}$ \\
\hline EGFR mutations: L858R or ex19del & $\begin{array}{l}45 / 613 \\
(7.3 \%)\end{array}$ & $\begin{array}{l}214 / 590 \\
(36.3 \%)\end{array}$ & $\begin{array}{c}211 / 1133 \\
(18.6 \%)\end{array}$ & $\begin{array}{c}470 / 2336 \\
(20.1 \%)\end{array}$ & $\mathrm{p}<2.2 \times 10^{-16}$ \\
\hline $\begin{array}{l}\text { ALK translocations } \\
\text { (EGFR-negative cases) }\end{array}$ & $\begin{array}{l}6 / 568 \\
(1.1 \%)\end{array}$ & $\begin{array}{l}32 / 376 \\
(8.5 \%)\end{array}$ & $\begin{array}{l}57 / 922 \\
(6.2 \%)\end{array}$ & $\begin{array}{c}95 / 1866 \\
(5.1 \%)\end{array}$ & $\mathrm{p}=3.1 \times 10^{-8}$ \\
\hline $\begin{array}{l}\text { KRAS mutations } \\
\text { (EGFR/ALK-negative cases) }\end{array}$ & $\begin{array}{l}151 / 483 \\
(31.3 \%)\end{array}$ & $\begin{array}{l}71 / 303 \\
(23.4 \%)\end{array}$ & $\begin{array}{l}172 / 584 \\
(29.5 \%)\end{array}$ & $\begin{array}{c}394 / 1370 \\
(28.8 \%)\end{array}$ & $\mathrm{p}=\mathbf{0 . 0 2 2}$ \\
\hline $\begin{array}{l}\text { BRAF V600E mutations }{ }^{\mathrm{a}} \\
\text { (EGFR/ALK/KRAS-negative cases) }^{\text {(EGR }}\end{array}$ & $\begin{array}{l}5 / 294 \\
(1.7 \%)\end{array}$ & $\begin{array}{l}8 / 195 \\
(4.1 \%)\end{array}$ & $\begin{array}{c}1 / 54 \\
\text { (age } \geq 70,1.9 \%)\end{array}$ & $\begin{array}{l}14 / 543 \\
(2.6 \%)\end{array}$ & $\mathrm{p}=0.183$ \\
\hline
\end{tabular}

${ }^{a}$ In addition, two cases with K601E mutation in the BRAF gene were also identified (0.7\%).

Table 3. KRAS mutation frequencies in EGFR/ALK mutation-negative lung adenocarcinomas ${ }^{\mathrm{a}}$.

\begin{tabular}{|c|c|c|c|c|c|c|}
\hline & & Ever-smokers & Never-smokers & $\begin{array}{c}\text { Smoking status } \\
\text { unknown }\end{array}$ & All & $\begin{array}{c}\text { Ever-smokers vs never-smokers, } \\
\text { Fisher's exact test }\end{array}$ \\
\hline 1 & G12C $($ GGT $>$ TGT $)$ & $64(13.3 \%)$ & $7(2.3 \%)$ & $58(9.9 \%)$ & $129(9.4 \%)$ & $\mathrm{p}=3.0 \times 10^{-8}$ \\
\hline 2 & G12D (GGT>GAT) & $20(4.1 \%)$ & $26(8.6 \%)$ & $35(6.0 \%)$ & $81(5.9 \%)$ & $\mathrm{p}=\mathbf{0 . 0 1 2}$ \\
\hline 3 & G12V (GGT>GTT) & $25(5.2 \%)$ & $14(4.6 \%)$ & $34(5.8 \%)$ & $73(5.3 \%)$ & $\mathrm{p}=0.866$ \\
\hline 4 & $\mathrm{G} 12 \mathrm{~A}(\mathrm{GGT}>\mathrm{GCT})$ & $8(1.7 \%)$ & $11(3.6 \%)$ & $11(1.9 \%)$ & $30(2.2 \%)$ & $\mathrm{p}=0.096$ \\
\hline 5 & $\mathrm{Q} 61 \mathrm{H}(\mathrm{CAA}>\mathrm{CAT} / \mathrm{CAC})$ & $6(1.2 \%)$ & $4(1.3 \%)$ & $7(1.2 \%)$ & $17(1.2 \%)$ & $\mathrm{p}=1.000$ \\
\hline 6 & G13C (GGC>TGC) & $3(0.6 \%)$ & $1(0.3 \%)$ & $9(1.5 \%)$ & $13(0.9 \%)$ & $\mathrm{p}=1.000$ \\
\hline 7 & G12S (GGT>AGT) & $2(0.4 \%)$ & $1(0.3 \%)$ & $8(1.4 \%)$ & $11(0.8 \%)$ & $\mathrm{p}=1.000$ \\
\hline 8 & G12R $($ GGT $>$ CGT $)$ & $5(1.0 \%)$ & $1(0.3 \%)$ & $4(0.7 \%)$ & $10(0.7 \%)$ & $\mathrm{p}=0.414$ \\
\hline 9 & G13D (GGC>GAC) & $5(1.0 \%)$ & $2(0.7 \%)$ & $1(0.2 \%)$ & $8(0.6 \%)$ & $\mathrm{p}=0.713$ \\
\hline 10 & Q61L $($ CAA $>$ CTA $)$ & $3(0.6 \%)$ & 0 & $1(0.2 \%)$ & $4(0.3 \%)$ & $\mathrm{p}=0.288$ \\
\hline 11 & Q61R $($ CAA $>$ CGA $)$ & $1(0.2 \%)$ & $2(0.7 \%)$ & $1(0.2 \%)$ & $4(0.3 \%)$ & $\mathrm{p}=0.563$ \\
\hline 12 & G12F $($ GGT $>$ TTT $)$ & $2(0.4 \%)$ & 0 & $1(0.2 \%)$ & $3(0.2 \%)$ & $\mathrm{p}=0.526$ \\
\hline 13 & $\mathrm{~A} 146 \mathrm{~T}(\mathrm{GCA}>\mathrm{ACA})$ & $1(0.2 \%)$ & $1(0.3 \%)$ & 0 & $2(0.1 \%)$ & $\mathrm{p}=1.000$ \\
\hline 14 & G13V (GGC>GTT) & $2(0.4 \%)$ & 0 & 0 & $2(0.1 \%)$ & $\mathrm{p}=0.526$ \\
\hline
\end{tabular}

${ }^{a}$ This table does not include variants, which were detected only in one case each: G12E, G13E, L19F, Y64C, A146P, A146V, A11G+G12C, G12C+G12D. 
Table 4. Nucleotide changes in KRAS gene among patients with EGFR and ALK-negative lung adenocarcinomas.

\begin{tabular}{|c|c|c|c|c|c|}
\hline & Ever-smokers & Never-smokers & $\begin{array}{l}\text { Smoking status un- } \\
\text { known }\end{array}$ & All & $\begin{array}{c}\text { Ever-smokers vs never-smokers, } \\
\text { Fisher's exact test }\end{array}$ \\
\hline Transversions & $142(29.4 \%)$ & $54(17.8 \%)$ & $167(28.6 \%)$ & $363(26.5 \%)$ & $\mathrm{p}=0.00026$ \\
\hline $\mathrm{G}>\mathrm{T}$ & $92(19.0 \%)$ & $22(7.3 \%)$ & $101(17.3 \%)$ & $215(15.7 \%)$ & $\mathrm{p}=3.6 \cdot 10^{-6}$ \\
\hline $\mathrm{G}>\mathrm{T}$, not $\mathrm{G} 12 \mathrm{C}$ & $28(5.8 \%)$ & $15(5.0 \%)$ & $43(7.4 \%)$ & $86(6.3 \%)$ & $\mathrm{p}=0.748$ \\
\hline $\mathrm{G}>\mathrm{C}$ & $14(2.9 \%)$ & $13(4.3 \%)$ & $15(2.6 \%)$ & $42(3.1 \%)$ & $\mathrm{p}=0.319$ \\
\hline $\mathrm{A}>\mathrm{C}$ & $3(0.6 \%)$ & $3(1.0 \%)$ & $4(0.7 \%)$ & $10(0.7 \%)$ & $\mathrm{p}=0.681$ \\
\hline $\mathrm{A}>\mathrm{T}$ & $6(1.2 \%)$ & $1(0.3 \%)$ & $4(0.7 \%)$ & $11(0.8 \%)$ & $\mathrm{p}=0.259$ \\
\hline Transitions & $29(6.0 \%)$ & $32(10.6 \%)$ & $47(8.0 \%)$ & $108(7.9 \%)$ & $\mathrm{p}=0.028$ \\
\hline $\mathrm{G}>\mathrm{A}$ & $28(5.8 \%)$ & $30(9.9 \%)$ & $44(7.5 \%)$ & $102(7.4 \%)$ & $p=\mathbf{0 . 0 3 6}$ \\
\hline$A>G$ & $1(0.2 \%)$ & $2(0.7 \%)$ & $1(0.2 \%)$ & $4(0.3 \%)$ & $\mathrm{p}=0.563$ \\
\hline $\mathrm{C}>\mathrm{T}$ & 0 & 0 & $1(0.2 \%)$ & $1(0.1 \%)$ & - \\
\hline $\mathrm{T}>\mathrm{C}$ & 0 & 0 & $1(0.2 \%)$ & $1(0.1 \%)$ & - \\
\hline Complex & $7(1.4 \%)$ & 0 & $2(0.3 \%)$ & $9(0.7 \%)$ & $\mathrm{p}=0.048$ \\
\hline dinucleotide & $6(1.2 \%)$ & 0 & $1(0.2 \%)$ & $7(0.5 \%)$ & $\mathrm{p}=0.087$ \\
\hline double & $1(0.2 \%)$ & 0 & $1(0.2 \%)$ & $2(0.1 \%)$ & $\mathrm{p}=1.000$ \\
\hline
\end{tabular}

Table 5. Overview of large-scale studies on actionable mutations in lung adenocarcinomas ${ }^{\mathrm{a}}$.

\begin{tabular}{|c|c|c|c|c|c|c|}
\hline Study & Lee et al. [26] & Hsu et al. [27] & Zheng et al. [28] & Kris et al. [29] & Barlesi et al. [25] & $\begin{array}{l}\text { Current } \\
\text { study }\end{array}$ \\
\hline Country & Korea & Taiwan & China & USA & France & Russia \\
\hline $\begin{array}{l}\text { Number of lung adeno- } \\
\text { carcinoma cases }\end{array}$ & 5015 & 1772 & 1407 & 1007 & 13425 & 2336 \\
\hline$\%$ of never-smokers & ND & $66.5 \%$ & $67 \%$ & $34 \%$ & ND & $49 \%$ \\
\hline EGFR mutations & $46 \%$ & $\begin{array}{c}55.7 \% \\
\text { L858R+ex19del: } \\
54.3 \%\end{array}$ & $61.5 \%$ & $\begin{array}{c}17 \% ; \\
\text { L858R+ex19del: } \\
16.6 \%\end{array}$ & $11.2 \%$ & $\begin{array}{c}\text { L858R+ex19del: } \\
20 \%\end{array}$ \\
\hline ever-smokers & ND & $39.5 \%$ & $41 \%$ & $9.5 \%$ & ND & $7 \%$ \\
\hline never-smokers & ND & $63.9 \%$ & $71.5 \%$ & $33 \%$ & ND & $36 \%$ \\
\hline KRAS mutations & $9.2 \%$ & $5 \%$ & $8.1 \%$ & $24 \%$ & $31.5 \%$ & $22 \%$ \\
\hline ever-smokers & ND & $12.3 \%$ & $16.8 \%$ & $34.9 \%$ & ND & $28.5 \%$ \\
\hline never-smokers & ND & $1.7 \%$ & $3.8 \%$ & $4 \%$ & ND & $13.5 \%$ \\
\hline ALK rearrangements & $7.2 \%$ & $\begin{array}{c}9.8 \% \\
(29 / 295 \text { for EGFR } \\
\text { wild-type cases })\end{array}$ & $5.3 \%$ & $8 \%$ & $5.1 \%$ & $4 \%$ \\
\hline ever-smokers & ND & $\begin{array}{l}6.8 \% \text { for EGFR } \\
\text { wild-type cases }\end{array}$ & $4.3 \%$ & $4.4 \%$ & ND & $1 \%$ \\
\hline never-smokers & ND & $\begin{array}{l}11.9 \% \text { for EGFR } \\
\text { wild-type cases }\end{array}$ & $5.7 \%$ & $15 \%$ & ND & $5.4 \%$ \\
\hline BRAF exon 15 (V600E) & ND & $0.6 \%$ & ND & $1 \%$ & $2.1 \%$ & $1.5 \%$ \\
\hline ever-smokers & ND & $0.7 \%$ & ND & $1.7 \%$ & ND & $1.1 \%$ \\
\hline never-smokers & ND & $0.7 \%$ & ND & $1 \%$ & ND & $1.8 \%$ \\
\hline $\begin{array}{l}\text { Comment on the study } \\
\text { design }\end{array}$ & $\begin{array}{l}\text { Single-center study; } \\
\text { no sufficient details } \\
\text { describing the way } \\
\text { of testing (sequen- } \\
\text { tial vs. parallel) }\end{array}$ & $\begin{array}{l}\text { Multicenter study; } \\
\text { all genetic tests } \\
\text { were performed in } \\
\text { parallel }\end{array}$ & $\begin{array}{l}\text { Single-center study; } \\
\text { all genetic tests } \\
\text { were performed in } \\
\text { parallel }\end{array}$ & $\begin{array}{l}\text { Multicenter study; } \\
\text { genetic tests were } \\
\text { performed in par- } \\
\text { allel in most cases; } \\
\text { racial distribution } \\
\text { is not specified }\end{array}$ & $\begin{array}{l}\text { Multicenter study; } \\
\text { no sufficient details } \\
\text { describing the way } \\
\text { of testing (sequen- } \\
\text { tial vs. parallel) }\end{array}$ & $\begin{array}{c}\text { Single-center study; } \\
\text { sequential testing }\end{array}$ \\
\hline
\end{tabular}

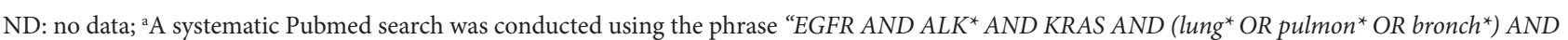
(cancer ${ }^{*}$ OR carcinoma ${ }^{*}$ OR tumor ${ }^{*}$ OR tumor ${ }^{*}$ OR adenocarcinoma ${ }^{*}$ ) AND English [language]". We considered all original reports describing frequencies of EGFR, ALK and KRAS mutations within a single study. By February 15th, 2018 the search retrieved 515 results, which were subjected to manual analysis. We included in the table all studies, which described distribution of EGFR, ALK and KRAS in more than 1000 lung adenocarcinomas. 
patient age (Supplementary Tables S1 and S2). Transitions tended to be associated with patient non-smoking status. Interestingly, dinucleotide substitutions were detected in 6 of 483 tumors observed in ever-smokers and in 1 of 584 tumors from patients with unknown smoking history, but not in any of 303 tumors from never-smokers (Fisher's exact test $\mathrm{p}$-value $=0.087)$.

BRAF V600E mutations constituted a significant proportion of EGFR/ALK/KRAS mutation-negative lung AdCa from non-smokers $(8 / 195,4 \%)$ and were less common in smokers $(5 / 294,1.7 \%)$. The frequency of BRAF V600E substitutions in female non-smokers was as high as $6.1 \%$. Median age of subjects with BRAF V600E mutations was evidently higher than in BRAF wild-type cases (72.5 vs. 63 years, $\mathrm{p}=0.008$ ).

We therefore analyzed an additional cohort of 54 elderly lung AdCa patients (70 years and over), however only one additional case of BRAF V600E mutation was identified (1.9\%). In addition, two instances of rare K601E mutation in BRAF were found by sequencing of HRM-positive samples: one sample was from a 79 years old non-smoking woman and the other from a 57 years old male smoker. Although the predictive role of $\mathrm{K} 601 \mathrm{E}$ mutation has not been systematically studied, available evidence suggests that it is not associated with response to inhibitors of mutated BRAF [22].

We then assessed if EGFR, ALK and KRAS mutations are mutually exclusive. ALK rearrangements were detected in 95/1,866 (5\%) EGFR mutation-negative tumors but only $1 / 470(0.2 \%)$ was found in AdCa with EGFR mutation. Similarly, KRAS mutations were common in EGFR wildtype AdCa (394/1418, 28\%), but there was only one instance (1.25\%) of concurrent KRAS lesion when we tested 80 carcinomas carrying EGFR mutation. KRAS testing of $48 \mathrm{AdCa}$ with ALK rearrangements did not reveal tumors with KRAS gene lesion. Therefore, sequential gene testing is an acceptable approach for lung cancer molecular diagnosis. The frequency of EGFR, ALK, KRAS and BRAF mutations in the Russian consecutive series of AdCa is estimated to be $20 \%, 4 \%, 22 \%$ and $1.5 \%$, respectively, being $7 \%, 1 \%, 28.5 \%$ and $1.1 \%$ in smokers and $36 \%, 5.4 \%, 13.5 \%$ and $1.8 \%$ in non-smokers.

\section{Discussion}

Although many studies describe the distribution of actionable mutations in lung cancer, most have limitations. For example, insufficient study size prevents consideration of important details such as explicit analysis of lung cancer clinical subsets and/or the distribution of some rare mutation categories. While many clinical investigations present relatively large data sets, they pool distinct histological types (for example, see $[23,24]$ ) or do not specify frequencies of mutations separately for smokers vs. non-smokers or men vs. women $[25,26]$. When comparing our results with published studies, we selected reports which recruited more than a thousand lung AdCa and provided data of EGFR, ALK and
KRAS mutation distribution. Only 5 prior studies met this criteria [25-29], with three performed in Asians [26-28] and two in countries with predominantly white population $[25,29]$. Furthermore, only three of these studies considered AdCa mutation frequency separately in smokers and non-smokers [27-29] (Table 5).

Referral bias can also significantly affect the results of mutation analysis in lung cancer. EGFR and ALK mutations are well known to be highly over-represented in non-smokers and women, therefore these categories of patients are likely to be preferred when considering molecular tests in clinical decision-making. Furthermore, the probability of finding EGFR mutations is significantly increased for Asians, thus providing a further source of referral bias in multi-racial countries. For example, the study of Kris et al. [29], which encouraged the tailoring of patients to approved or investigational targeted drugs, included large number of patients with AdCa and considered smoking history when calculating mutation frequencies (Table 5). Interestingly, the proportion of never-smokers, EGFR mutations and ALK translocations in the study of Kris et al. [29] is somewhat higher than in the majority of Western studies [25, 30, 31]; authors did not comment on the race of the recruited patients [29]. Therefore, it is possible that the inclusion of Asian descent patients could contribute to the elevated frequency of EGFR mutations.

The series presented in this study consisted of patients who were referred for genetic analysis by their primary physicians. In order to evaluate referral bias, we compared our current data set (years 2013-2016) with our previous study, where all surgically resected lung AdCa cases (years 2000 - 2005) were consecutively collected from the pathological archive [32]. Here, it is essential to emphasize that all relevant data from the current clinical collection was virtually identical to that in our previous investigation involving consecutive lung AdCa (EGFR mutation frequency 470/2336 (20.1\%) vs. 38/192 (19.8\%); proportion of 'never-smokers': 590/1203 (49\%) vs. 94/192 (49\%); proportion of women: $962 / 2336(41.2 \%)$ vs. $76 / 192(39.6 \%))$. This is an important indicator, demonstrating that all patients with lung AdCa are currently referred for genetic testing irrespective of smoking history and gender. This lack of referral bias reflects current situation with lung cancer treatment in Russia, where firstgeneration EGFR tyrosine kinase inhibitors are fully accessible to all patients with TKI sensitizing mutations and health professionals are encouraged to perform EGFR testing for all patients with non-squamous lung cancer.

Adenocarcinoma is a predominant type of lung cancer in the Western world, and its high incidence is largely attributed to the consumption of low-tar cigarettes. In contrast to Western countries, where most lung AdCa patients are smokers, approximately half of Russian lung AdCa are observed in non-smokers. This study is therefore one of the largest series of smoking-unrelated lung AdCa collected in European patients. 
Distribution of KRAS mutations in lung AdCa has also been analyzed in a number of studies. It is frequently stated that the occurrence of KRAS mutations is significantly higher in smokers compared to non-smokers [33, 34]. However, this conclusion is certainly true only for non-selected patients with lung AdCa. If one considers the most common actionable LC mutations, which affect EGFR and ALK genes, these are characterized by low occurrence in smokers but account for almost half of AdCa in white non-smokers. Accordingly, when we exclude patients who are candidates for tyrosine kinase inhibitor therapy, smoking is no longer a factor considerably affecting the likelihood of finding the KRAS mutation.

Furthermore, while some KRAS mutations are indeed more prevalent in smokers, other types of substitutions in this gene are clearly associated with no tobacco consumption. The lung tumors in smokers usually carry a large overall number of transversions, while transitions are characteristic for smoking-independent cancers [35]. Although several reports demonstrate that this trend applies to KRAS mutations [36-38], we found that only KRAS G12C transversion is more commonly observed in smokers vs. non-smokers, while frequencies of other KRAS transversions are independent of smoking status. If drugs targeting KRASmutated lung cancers eventually enter clinical practice, it will be essential to consider all these data in order to ensure that both smokers and non-smokers have equal chance of being tested for KRAS status.

Use of combined inhibition of mutated BRAF kinase and MEK kinase was shown to be a viable approach in treating lung cancer with BRAF V600E substitution. Unlike with EGFR, ALK and KRAS, associations with clinical parameters for BRAF mutations are less defined and this is mainly due to the limited number of published studies. Two meta-analyses indicated higher prevalence of BRAF V600E mutation in females and never-smokers [39, 40], thus supporting our findings. The overall frequency of BRAF V600E mutation in Russian lung AdCa patients is estimated to be approximately $1.5 \%$ which is at the lower limit of variations reported in patients of European origin (1.6-2.8\%) [41-43], but it is higher than the frequency observed in Asian patients [27, 44]. This difference is likely to be explained by the larger proportion of EGFR-mutant lung AdCa cases in East Asia compared to Europe [45] with intermediate frequency characteristic of the Russian series $[16,32]$.

Several studies [46-48] demonstrated frequent co-occurrence of driver mutations in lung AdCa. Notably, one of these studies utilized extremely sensitive methods to detect concomitant mutations present in rare sub-populations of tumor cells [48]. The clinical significance of such findings is yet to be determined. Our data highlights that concurrent presence of EGFR, ALK and KRAS mutations is very rare, at least when moderately sensitive assays, such as high-resolution melting analysis (HRM), are used in mutation screening; and this finding is in agreement with most published data.
While next-generation sequencing and simultaneous testing of all potentially relevant genes is likely to replace current diagnostic methods in lung cancer molecular analysis in the near future, now personalized prescription of molecular tests remains standard clinical practice in most cancer clinics worldwide. This study confirms the reliability of sequential lung cancer testing for actionable mutations, and describes the previously unrecognized peculiarities in their distribution.

Supplementary information is available in the online version of the paper.

Acknowledgements: This study was supported by Russian Scientific Fund (grant 16-15-10396) and Russian Society of Clinical Oncology.

\section{References}

[1] LYNCH TJ, BELL DW, SORDELLA R, GURUBHAGAVATULA S, OKIMOTO RA et al. Activating mutations in the epidermal growth factor receptor underlying responsiveness of non-small-cell lung cancer to gefitinib. N Engl J Med 2004; 350: 2129-2139. https://doi.org/10.1056/NEJMoa040938

[2] PAEZ JG, JANNE PA, LEE JC, TRACY S, GREULICH H et al. EGFR mutations in lung cancer: correlation with clinical response to gefitinib therapy. Science 2004; 304: 1497-1500. https://doi.org/10.1126/science.1099314

[3] PAO W, MILLER V, ZAKOWSKI M, DOHERTY J, POLITI $\mathrm{K}$ et al. EGF receptor gene mutations are common in lung cancers from "never smokers" and are associated with sensitivity of tumors to gefitinib and erlotinib. Proc Natl Acad Sci U S A 2004; 101: 13306-13311. https://doi.org/10.1073/ pnas.0405220101

[4] SULLIVAN I, PLANCHARD D. ALK inhibitors in nonsmall cell lung cancer: the latest evidence and developments. Ther Adv Med Oncol 2016; 8: 32-47. https://doi. org/10.1177/1758834015617355

[5] JANNE PA, SHAW AT, PEREIRA JR, JEANNIN G, VANSTEENKISTE $J$ et al. Selumetinib plus docetaxel for KRAS-mutant advanced non-small-cell lung cancer: a randomised, multicentre, placebo-controlled, phase 2 study. Lancet Oncol 2013; 14: 38-47. https://doi.org/10.1016/ S1470-2045(12)70489-8

[6] JANNE PA, SMITH I, MCWALTER G, MANN H, DOUGHERTY B et al. Impact of KRAS codon subtypes from a randomised phase II trial of selumetinib plus docetaxel in KRAS mutant advanced non-small-cell lung cancer. Br J Cancer 2015; 113: 199-203. https://doi.org/10.1038/bjc.2015.215

[7] JANNE PA, VAN DEN HEUVEL MM, BARLESI F, COBO M, MAZIERES J et al. Selumetinib Plus Docetaxel Compared With Docetaxel Alone and Progression-Free Survival in Patients With KRAS-Mutant Advanced Non-Small Cell Lung Cancer: The SELECT-1 Randomized Clinical Trial. JAMA 2017; 317: 1844-1853. https://doi.org/10.1001/ jama.2017.3438 
[8] HYMAN DM, PUZANOV I, SUBBIAH V, FARIS JE, CHAU I et al. Vemurafenib in Multiple Nonmelanoma Cancers with BRAF V600 Mutations. N Engl J Med 2015; 373: 726-736. https://doi.org/10.1056/NEJMoa1502309

[9] PLANCHARD D, BESSE B, GROEN HJ, SOUQUET PJ, QUOIX E et al. Dabrafenib plus trametinib in patients with previously treated BRAF(V600E)-mutant metastatic nonsmall cell lung cancer: an open-label, multicentre phase 2 trial. Lancet Oncol 2016; 17: 984-993. https://doi.org/10.1016/ S1470-2045(16)30146-2

[10] PLANCHARD D, KIM TM, MAZIERES J, QUOIX E, RIELY $\mathrm{G}$ et al. Dabrafenib in patients with BRAF(V600E)-positive advanced non-small-cell lung cancer: a single-arm, multicentre, open-label, phase 2 trial. Lancet Oncol 2016; 17: 642-650. https://doi.org/10.1016/S1470-2045(16)00077-2

[11] DE GREVE J, MORAN T, GRAAS MP, GALDERMANS D, VUYLSTEKE $P$ et al. Phase II study of afatinib, an irreversible ErbB family blocker, in demographically and genotypically defined lung adenocarcinoma. Lung Cancer 2015; 88: 63-69. https://doi.org/10.1016/j.lungcan.2015.01.013

[12] GAUTSCHI O, MILIA J, FILLERON T, WOLF J, CARBONE DP et al. Targeting RET in Patients With RET-Rearranged Lung Cancers: Results From the Global, Multicenter RET Registry. J Clin Oncol 2017; 35: 1403-1410. https://doi. org/10.1200/JCO.2016.70.9352

[13] MAZIERES J, ZALCMAN G, CRINO L, BIONDANI P, BARLESI $\mathrm{F}$ et al. Crizotinib therapy for advanced lung adenocarcinoma and a ROS1 rearrangement: results from the EUROS1 cohort. J Clin Oncol 2015; 33: 992-999. https://doi. org/10.1200/JCO.2014.58.3302

[14] REUNGWETWATTANA T, LIANG Y, ZHU V, OU SI. The race to target MET exon 14 skipping alterations in non-small cell lung cancer: The Why, the How, the Who, the Unknown, and the Inevitable. Lung Cancer 2017; 103: 27-37. https:// doi.org/10.1016/j.lungcan.2016.11.011

[15] DEMIDOVA I, GRINEVICH V, AVDALIAN A, IMYANITOV E, GIKALO M et al. Detection of ALK rearrangements in 4002 Russian patients: The utility of different diagnostic approaches. Lung Cancer 2017; 103: 17-23. https://doi. org/10.1016/j.lungcan.2016.11.001

[16] IMYANITOV EN, DEMIDOVA IA, GORDIEV MG, FILIPENKO ML, KEKEYEVA TV et al. Distribution of EGFR Mutations in 10,607 Russian Patients with Lung Cancer. Mol Diagn Ther 2016; 20: 401-406. https://doi.org/10.1007/ s40291-016-0213-4

[17] ALI G, PROIETTI A, PELLICCIONI S, NICCOLI C, LUPI $\mathrm{C}$ et al. ALK rearrangement in a large series of consecutive non-small cell lung cancers: comparison between a new immunohistochemical approach and fluorescence in situ hybridization for the screening of patients eligible for crizotinib treatment. Arch Pathol Lab Med 2014; 138: 1449-1458. https://doi.org/10.5858/arpa.2013-0388-OA

[18] GAINOR JF, VARGHESE AM, OU SH, KABRAJI S, AWAD $\mathrm{MM}$ et al. ALK rearrangements are mutually exclusive with mutations in EGFR or KRAS: an analysis of 1,683 patients with non-small cell lung cancer. Clin Cancer Res 2013; 19: 4273-4281. https://doi.org/10.1158/1078-0432.CCR-130318
[19] MITIUSHKINA NV, IYEVLEVA AG, POLTORATSKIY AN, IVANTSOV AO, TOGO AV et al. Detection of EGFR mutations and EML4-ALK rearrangements in lung adenocarcinomas using archived cytological slides. Cancer Cytopathol 2013; 121: 370-376. https://doi.org/10.1002/ cncy. 21281

[20] IYEVLEVA AG, RASKIN GA, TIURIN VI, SOKOLENKO AP, MITIUSHKINA NV et al. Novel ALK fusion partners in lung cancer. Cancer Lett 2015; 362: 116-121. https://doi. org/10.1016/j.canlet.2015.03.028

[21] YANUS GA, BELYAEVA AV, IVANTSOV AO, KULIGINA ESH, SUSPITSIN EN et al. Pattern of clinically relevant mutations in consecutive series of Russian colorectal cancer patients. Med Oncol 2013; 30: 686. https://doi.org/10.1007/ s12032-013-0686-5

[22] FALCHOOK GS, LONG GV, KURZROCK R, KIM KB, ARKENAU TH et al. Dabrafenib in patients with melanoma, untreated brain metastases, and other solid tumors: a phase 1 dose-escalation trial. Lancet 2012; 379: 1893-1901. https:// doi.org/10.1016/S0140-6736(12)60398-5

[23] GOBBINI E, GALETTA D, TISEO M, GRAZIANO P, ROSSI A et al. Molecular profiling in Italian patients with advanced non-small-cell lung cancer: An observational prospective study. Lung Cancer 2017; 111: 30-37. https://doi. org/10.1016/j.lungcan.2017.06.009

[24] SUH JH, JOHNSON A, ALBACKER L, WANG K, CHMIELECKI J et al. Comprehensive Genomic Profiling Facilitates Implementation of the National Comprehensive Cancer Network Guidelines for Lung Cancer Biomarker Testing and Identifies Patients Who May Benefit From Enrollment in Mechanism-Driven Clinical Trials. Oncologist 2016; 21: 684-691. https://doi.org/10.1634/theoncologist.2016-0030

[25] BARLESI F, MAZIERES J, MERLIO JP, DEBIEUVRE D, MOSSER J et al. Routine molecular profiling of patients with advanced non-small-cell lung cancer: results of a 1-year nationwide programme of the French Cooperative Thoracic Intergroup (IFCT). Lancet 2016; 387: 1415-1426. https://doi. org/10.1016/S0140-6736(16)00004-0

[26] LEE B, LEE T, LEE SH, CHOI YL, HAN J. Clinicopathologic characteristics of EGFR, KRAS, and ALK alterations in 6,595 lung cancers. Oncotarget 2016; 7: 23874-23884. https://doi. org/10.18632/oncotarget.8074

[27] HSU KH, HO CC, HSIA TC, TSENG JS, SU KY et al. Identification of five driver gene mutations in patients with treatment-naïve lung adenocarcinoma in Taiwan. PLoS One 2015; 10: e0120852. https://doi.org/10.1371/journal. pone.0120852

[28] ZHENG D, WANG R, ZHANG Y, PAN Y, CHENG X et al. Prevalence and clinicopathological characteristics of ALK fusion subtypes in lung adenocarcinomas from Chinese populations. J Cancer Res Clin Oncol 2016; 142: 833-843. https://doi.org/10.1007/s00432-015-2081-4

[29] KRIS MG, JOHNSON BE, BERRY LD, KWIATKOWSKI DJ, IAFRATE AJ et al. Using multiplexed assays of oncogenic drivers in lung cancers to select targeted drugs. JAMA 2014; 311: 1998-2006. https://doi.org/10.1001/ jama.2014.3741 
[30] SCHWEGLER C, KAUFMANN D, PFEIFFER D, AEBI S, DIEBOLD J et al. Population-level effect of molecular testing and targeted therapy in patients with advanced pulmonary adenocarcinoma: a prospective cohort study. Virchows Arch 2018; 472: 581-588. https://doi.org/10.1007/s00428-0172268-y

[31] CHATZIANDREOU I, TSIOLI P, SAKELLARIOU S, MOURKIOTI I, GIANNOPOULOU I et al. Comprehensive Molecular Analysis of NSCLC; Clinicopathological Associations. PLoS One 2015; 10: e0133859. https://doi.org/10.1371/ journal.pone.0133859

[32] MOISEYENKO VM, PROCENKO SA, LEVCHENKO EV, BARCHUK AS, MOISEYENKO FV et al. High efficacy of first-line gefitinib in non-Asian patients with EGFR-mutated lung adenocarcinoma. Onkologie 2010; 33: 231-238. https:// doi.org/10.1159/000302729

[33] CHAPMAN AM, SUN KY, RUESTOW P, COWAN DM, MADL AK. Lung cancer mutation profile of EGFR, ALK, and KRAS: Meta-analysis and comparison of never and ever smokers. Lung Cancer 2016; 102: 122-134. https://doi. org/10.1016/j.lungcan.2016.10.010

[34] ZHENG D, WANG R, ZHANG Y, PAN Y, CHENG X et al. The prevalence and prognostic significance of KRAS mutation subtypes in lung adenocarcinomas from Chinese populations. Onco Targets Ther 2016; 9: 833-843. https://doi. org/10.2147/OTT.S96834

[35] GOVINDAN R, DING L, GRIFFITH M, SUBRAMANIAN J, DEES ND et al. Genomic landscape of non-small cell lung cancer in smokers and never-smokers. Cell 2012; 150: 11211134. https://doi.org/10.1016/j.cell.2012.08.024

[36] DUMENIL C, VIEIRA T, ROULEAU E, ANTOINE M, DURUISSEAUX $\mathrm{M}$ et al. Is there a specific phenotype associated with the different subtypes of KRAS mutations in patients with advanced non-small-cell lung cancers? Lung Cancer 2015; 90: 561-567. https://doi.org/10.1016/j.lungcan.2015.10.012

[37] RIELY GJ, KRIS MG, ROSENBAUM D, MARKS J, LI A et al. Frequency and distinctive spectrum of KRAS mutations in never smokers with lung adenocarcinoma. Clin Cancer Res 2008; 14: 5731-5734. https://doi.org/10.1158/1078-0432. CCR-08-0646

[38] TAKAMOCHI K, OH S, SUZUKI K. Differences in EGFR and KRAS mutation spectra in lung adenocarcinoma of never and heavy smokers. Oncol Lett 2013; 6: 1207-1212. https://doi.org/10.3892/ol.2013.1551
[39] CHEN D, ZHANG LQ, HUANG JF, LIU K, CHUAI ZR et al. BRAF mutations in patients with non-small cell lung cancer: a systematic review and meta-analysis. PLoS One 2014; 9: e101354. https://doi.org/10.1371/journal.pone.0101354

[40] CUI G, LIU D, LI W, FU X, LIANG Y et al. A meta-analysis of the association between BRAF mutation and nonsmall cell lung cancer. Medicine (Baltimore). 2017; 96: e6552. https:// doi.org/10.1097/MD.0000000000006552

[41] BRUSTUGUN OT, KHATTAK AM, TROMBORG AK, BEIGI $\mathrm{M}$, BEISKE $\mathrm{K}$ et al. BRAF-mutations in non-small cell lung cancer. Lung Cancer 2014; 84: 36-38. https://doi. org/10.1016/j.lungcan.2014.01.023

[42] MARCHETTI A, FELICIONI L, MALATESTA S, GRAZIA SCIARROTTA M, GUETTI L et al. Clinical features and outcome of patients with non-small-cell lung cancer harboring BRAF mutations. J Clin Oncol 2011; 29: 3574-3579. https:// doi.org/10.1200/JCO.2011.35.9638

[43] TISSOT C, COURAUD S, TANGUY R, BRINGUIER PP, GIRARD $\mathrm{N}$ et al. Clinical characteristics and outcome of patients with lung cancer harboring BRAF mutations. Lung Cancer 2016; 91: 23-28. https://doi.org/10.1016/j.lungcan.2015.11.006

[44] KINNO T, TSUTA K, SHIRAISHI K, MIZUKAMI T, SUZUKI $\mathrm{M}$ et al. Clinicopathological features of nonsmall cell lung carcinomas with BRAF mutations. Ann Oncol 2014; 25: 138-142. https://doi.org/10.1093/annonc/mdt495

[45] ZHOU W, CHRISTIANI DC. East meets West: ethnic differences in epidemiology and clinical behaviors of lung cancer between East Asians and Caucasians. Chin J Cancer 2011; 30: 287-292.

[46] SAHNANE N, FRATTINI M, BERNASCONI B, ZAPPA F, SCHIAVONE G et al. EGFR and KRAS Mutations in ALK-Positive Lung Adenocarcinomas: Biological and Clinical Effect. Clin Lung Cancer 2016; 17: 56-61. https://doi. org/10.1016/j.cllc.2015.08.001

[47] ULIVI P, CHIADINI E, DAZZI C, DUBINI A, COSTANTINI M et al. Nonsquamous, Non-Small-Cell Lung Cancer Patients Who Carry a Double Mutation of EGFR, EML4ALK or KRAS: Frequency, Clinical-Pathological Characteristics, and Response to Therapy. Clin Lung Cancer 2016; 17: 384-390. https://doi.org/10.1016/j.cllc.2015.11.004

[48] WON JK, KEAM B, KOH J, CHO HJ, JEON YK et al. Concomitant ALK translocation and EGFR mutation in lung cancer: a comparison of direct sequencing and sensitive assays and the impact on responsiveness to tyrosine kinase inhibitor. Ann Oncol 2015; 26: 348-354. https://doi.org/10.1093/ annonc/mdu530 


\section{Supplementary Methods}

Supplementary Methods Table 1. PCR tests design: primers, probes and conditions.

\begin{tabular}{|c|c|c|c|c|}
\hline Test & $\begin{array}{l}\text { PCR composition and } \\
\text { conditions }\end{array}$ & \multicolumn{2}{|c|}{$\begin{array}{l}\text { Primers: forward; } \\
\text { reverse; } \\
\text { TaqMan probe / pyrosequencing primer (where applicable) }\end{array}$} & $\begin{array}{l}\text { PCR } \\
\text { fragment } \\
\text { length }\end{array}$ \\
\hline \multicolumn{5}{|c|}{ EGFR gene $^{\mathrm{a}}$} \\
\hline $\begin{array}{l}\text { PCR followed } \\
\text { by gel- } \\
\text { electrophoresis }\end{array}$ & $\begin{array}{l}10 \text { mkl volume reaction: } 1-\mathrm{x} \\
\text { GeneAmp PCR buffer I } \\
\text { (Applied Biosystems), } 0.5 \mathrm{U} \\
\text { Taq M hot-start DNA } \\
\text { polymerase (AlkorBio), } 2.5 \\
\text { mM } \mathrm{MgCl}_{2}, 250 \mathrm{mkM} \mathrm{dNTP}, \\
200 \mathrm{nM} \text { primers. } \\
\text { PCR program: } 95^{\circ} \mathrm{C} 10 \mathrm{~min}, \\
\text { followed by } 45 \text { cycles }\left(95^{\circ} \mathrm{C} 20\right. \\
\left.\text { sec, } 58^{\circ} \mathrm{C} 30 \mathrm{sec}, 72^{\circ} \mathrm{C} 30 \mathrm{sec}\right) . \\
\text { Device: } \mathrm{MyCycler}(\mathrm{Bio}-\mathrm{Rad}) .\end{array}$ & \multicolumn{2}{|c|}{$\begin{array}{l}\text { CTGTCATAGGGACTCTGGAT; } \\
\text { CAGCAAAGCAGAAACTCACAT }\end{array}$} & $\begin{array}{l}127 \mathrm{bp} \\
\text { (WT allele) }\end{array}$ \\
\hline \multirow{2}{*}{$\begin{array}{l}\text { Real-time AS- } \\
\text { PCR for L858R } \\
\text { mutation }\end{array}$} & \multirow{2}{*}{$\begin{array}{l}20 \text { mkl volume reaction: } 1-x \\
\text { GeneAmp PCR buffer I } \\
\text { (Applied Biosystems), } 1 \mathrm{U} \text { Taq } \\
\text { M hot-start DNA polymerase } \\
\text { (AlkorBio), } 2.5 \mathrm{mM} \mathrm{MgCl} 2 \text {, } \\
250 \mathrm{mkM} \text { dNTP, } 1 \text {-x SYBR } \\
\text { Green I, } 100 \mathrm{nM} \text { primers. } \\
\text { PCR program: } 95^{\circ} \mathrm{C} 10 \mathrm{~min}, \\
\text { followed by } 45 \text { cycles }\left(95^{\circ} \mathrm{C} 15\right. \\
\text { sec, } 60^{\circ} \mathrm{C} 30 \mathrm{sec}, 72^{\circ} \mathrm{C} 30 \mathrm{sec} \text { ), } \\
\text { then melting from } 65^{\circ} \mathrm{C} \text { to } \\
95^{\circ} \mathrm{C} \text {. } \\
\text { Device: } \mathrm{CFX} 96 \text { (Bio-Rad). }\end{array}$} & $\begin{array}{l}\text { WT-specific } \\
\text { reaction }\end{array}$ & $\begin{array}{l}\text { GCATGAACTACTTGGAGGAC; } \\
\text { TCCGCACCCAGCAGTTTGGCTA }\end{array}$ & 120 bp \\
\hline & & $\begin{array}{l}\text { L858R-specific } \\
\text { reaction }\end{array}$ & $\begin{array}{l}\text { GCATGAACTACTTGGAGGAC; } \\
\text { TCCGCACCCAGCAGTTTGGCTC }\end{array}$ & $120 \mathrm{bp}$ \\
\hline \multicolumn{5}{|c|}{ ALK gene $^{b}$} \\
\hline \multirow{2}{*}{$\begin{array}{l}\text { Test for } \\
\text { unbalanced } \\
\text { 3'/5'-end ALK } \\
\text { expression } \\
\text { (qPCR) }\end{array}$} & \multirow{2}{*}{$\begin{array}{l}20 \text { mkl volume reaction: } 1-\mathrm{x} \\
\text { GeneAmp PCR buffer I } \\
\text { (Applied Biosystems), } 1 \mathrm{U} \text { Taq } \\
\text { M hot-start DNA polymerase } \\
\text { (AlkorBio), } 2.5 \mathrm{mM} \mathrm{MgCl}_{2}, \\
250 \mathrm{mkM} \text { of dNTP, } 175 \mathrm{nM} \\
\text { primers and TaqMan probe. } \\
\text { PCR program: } 95^{\circ} \mathrm{C}, 10 \mathrm{~min}- \\
50 \text { cycles }\left(95^{\circ} \mathrm{C} 15 \mathrm{sec}, 60^{\circ} \mathrm{C} 1\right. \\
\text { min) } \\
\text { Device: } \mathrm{CFX} 96(\mathrm{Bio}-\mathrm{Rad})\end{array}$} & $\begin{array}{l}5 \text { '-end } \\
\text { amplification } \\
(\text { exons } 9-11)\end{array}$ & $\begin{array}{l}\text { CCTCTCCTCGATGTGTCTGA; } \\
\text { CTTGTCCTCTCCGCTAATGGT; } \\
\text { FAM-CATCGTGGCTTTTGACAATATCTC-BHQ1 }\end{array}$ & $135 \mathrm{bp}$ \\
\hline & & $\begin{array}{l}3 \text { '-end } \\
\text { amplification } \\
\text { (exons 22-23) }\end{array}$ & $\begin{array}{l}\text { TGTGCTCTGAACAGGACGAACT; } \\
\text { TGAGCTCCAGCAGGATGAACC; } \\
\text { FAM-ATGGAAGCCCTGATCATCAGCAAAT-BHQ1 }\end{array}$ & $132 \mathrm{bp}$ \\
\hline
\end{tabular}




\begin{tabular}{|c|c|c|c|c|}
\hline Test & $\begin{array}{l}\text { PCR composition and } \\
\text { conditions }\end{array}$ & \multicolumn{2}{|c|}{$\begin{array}{l}\text { Primers: forward; } \\
\text { reverse; } \\
\text { TaqMan probe / pyrosequencing primer (where applicable) }\end{array}$} & $\begin{array}{l}\text { PCR } \\
\text { fragment } \\
\text { length }\end{array}$ \\
\hline \multirow[t]{16}{*}{$\begin{array}{l}\text { Detection of } \\
\text { specific ALK } \\
\text { fusions (qPCR) }\end{array}$} & \multirow{16}{*}{$\begin{array}{l}20 \text { mkl volume reaction: } 1-\mathrm{x} \\
\text { GeneAmp PCR buffer I } \\
\text { (Applied Biosystems), } 1 \mathrm{U} \text { Taq } \\
\text { M hot-start DNA polymerase } \\
\text { (AlkorBio), } 2.5 \mathrm{mM} \mathrm{MgCl}_{2}, \\
250 \mathrm{mkM} \text { dNTP. } 175 \mathrm{nM} \\
\text { primers and TaqMan probe. } \\
\text { PCR program: } 95^{\circ} \mathrm{C}, 10 \mathrm{~min}- \\
50 \text { cycles }\left(95^{\circ} \mathrm{C} 15 \mathrm{sec}, 60^{\circ} \mathrm{C} 1\right. \\
\text { min) } \\
\text { Device: } \mathrm{CFX} 96(\mathrm{Bio}-\mathrm{Rad})\end{array}$} & $\begin{array}{l}\text { EML4ex13; } \\
\text { ALKex20 (V.1) }\end{array}$ & $\begin{array}{l}\text { TGGAGCAAAACTACTGTAGAG; } \\
\text { GTCGAGGTGCGGAGCTTG; } \\
\text { FAM-CTTGCTCAGCTTGTACTCAGGGC-BHQ1 }\end{array}$ & 134 bp \\
\hline & & $\begin{array}{l}\text { EML4ex20; } \\
\text { ALKex20 (V.2) }\end{array}$ & $\begin{array}{l}\text { CTAACTCGGGAGACTATGAAAT; } \\
\text { GTCGAGGTGCGGAGCTTG; } \\
\text { FAM-CTTGCTCAGCTTGTACTCAGGGC-BHQ1 }\end{array}$ & 118 bp \\
\hline & & $\begin{array}{l}\text { EML4ex6; } \\
\text { ALKex20(V.3a/b) }\end{array}$ & $\begin{array}{l}\text { CATAAAGATGTCATCATCAACCA; } \\
\text { GTCGAGGTGCGGAGCTTG; } \\
\text { FAM-CTTGCTCAGCTTGTACTCAGGGC-BHQ1 }\end{array}$ & $\begin{array}{l}\text { V3a- } \\
113 \text { bp } \\
\text { V3b- } \\
146 \text { bp } \\
\end{array}$ \\
\hline & & $\begin{array}{l}\text { EML4ex15; } \\
\text { ALKex20(V.8) }\end{array}$ & $\begin{array}{l}\text { AGTATGGCACAATCAGAGCTG; } \\
\text { TAGTTGGGGTTGTAGTCGGT; } \\
\text { FAM-ATTTTTAGTAGGCAAGCTCCGCAC-BHQ1 } \\
\end{array}$ & $100 \mathrm{bp}$ \\
\hline & & $\begin{array}{l}\text { EML4ex18; } \\
\text { ALKex20 (V.9) }\end{array}$ & $\begin{array}{l}\text { ACACAGACGGGAATGAACAG; } \\
\text { GTCGAGGTGCGGAGCTTG; } \\
\text { FAM-CTTGCTCAGCTTGTACTCAGGGC-BHQ1 }\end{array}$ & 133 bp \\
\hline & & $\begin{array}{l}\text { EMLex2; } \\
\text { ALKex20 (V.5a) }\end{array}$ & $\begin{array}{l}\text { GCAATCTCTGAAGATCATGTG; } \\
\text { GTCGAGGTGCGGAGCTTG; } \\
\text { FAM-CTTGCTCAGCTTGTACTCAGGGC-BHQ1 }\end{array}$ & $140 \mathrm{bp}$ \\
\hline & & $\begin{array}{l}\text { EMLex2; } \\
\text { ins117ALKex20 } \\
(\mathrm{V} .5 \mathrm{~b})\end{array}$ & $\begin{array}{l}\text { GCAATCTCTGAAGATCATGTG; } \\
\text { TACACAGGCCACTTCCTACA; } \\
\text { FAM-CAGTCTCAAGTAAAGGTTCAGAGC-BHQ1 }\end{array}$ & $115 \mathrm{bp}$ \\
\hline & & $\begin{array}{l}\text { EMLex14; } \\
\text { ins11del49ALKex20 } \\
\text { (V.4), } \\
\text { EMLex14; } \\
\text { del12ALKex20 (V.7) }\end{array}$ & $\begin{array}{l}\text { TGGAGGAGGGAAAGACAGA; } \\
\text { GTCGAGGTGCGGAGCTTG; } \\
\text { FAM-CTTGCTCAGCTTGTACTCAGGGC-BHQ1 }\end{array}$ & $\begin{array}{l}\text { V4 - } \\
117 \text { bp } \\
\text { V7- } \\
142 \text { bp }\end{array}$ \\
\hline & & $\begin{array}{l}\text { EMLex13; } \\
\text { ins69 ALKex20 (V.6) }\end{array}$ & $\begin{array}{l}\text { TGGAGCAAAACTACTGTAGAG; } \\
\text { TGGCCCTTGAAGCACTACAC; } \\
\text { FAM-GGAAAGGACCTAAAGGAAGTGGC-BHQ1 }\end{array}$ & $76 \mathrm{bp}$ \\
\hline & & $\begin{array}{l}\text { KIF5Bex24; } \\
\text { ALKex20 }\end{array}$ & $\begin{array}{l}\text { CGCATAAAGGAAGCAGTCAG; } \\
\text { GTCGAGGTGCGGAGCTTG; } \\
\text { FAM-CTTGCTCAGCTTGTACTCAGGGC-BHQ1 }\end{array}$ & 149 bp \\
\hline & & $\begin{array}{l}\text { KIF5Bex17; } \\
\text { ALKex } 20\end{array}$ & $\begin{array}{l}\text { CGATGCCCTCAGTGAAGAAC; } \\
\text { GTCGAGGTGCGGAGCTTG; } \\
\text { FAM-CTTGCTCAGCTTGTACTCAGGGC-BHQ1 } \\
\end{array}$ & 129 bp \\
\hline & & $\begin{array}{l}\text { KIF5Bex } 15 ; \\
\text { ALKex } 20\end{array}$ & $\begin{array}{l}\text { AGCAGCTGAGATGATGGCA; } \\
\text { GTCGAGGTGCGGAGCTTG; } \\
\text { FAM-CTTGCTCAGCTTGTACTCAGGGC-BHQ1 }\end{array}$ & 164 bp \\
\hline & & $\begin{array}{l}\text { TFGex3; } \\
\text { ALKex20 }\end{array}$ & $\begin{array}{l}\text { AGTAGGATACTGAAACTGACAT; } \\
\text { GTCGAGGTGCGGAGCTTG; } \\
\text { FAM-CTTGCTCAGCTTGTACTCAGGGC-BHQ1 }\end{array}$ & $116 \mathrm{bp}$ \\
\hline & & $\begin{array}{l}\text { KLC1ex9; } \\
\text { ALKex20 }\end{array}$ & $\begin{array}{l}\text { TCTCACTCGTGCACATGAAAG; } \\
\text { GTCGAGGTGCGGAGCTTG; } \\
\text { FAM-CTTGCTCAGCTTGTACTCAGGGC-BHQ1 }\end{array}$ & 129 bp \\
\hline & & $\begin{array}{l}\text { DCTN_ex26; } \\
\text { ALKex20 }\end{array}$ & $\begin{array}{l}\text { CTGGTCTCTGGCATTGCTG; } \\
\text { GTCGAGGTGCGGAGCTTG; } \\
\text { FAM-CTTGCTCAGCTTGTACTCAGGGC-BHQ1 }\end{array}$ & 104 bp \\
\hline & & $\begin{array}{l}\text { SQSTM1ex5; } \\
\text { ALKex20 }\end{array}$ & $\begin{array}{l}\text { TGAAGAACGTTGGGGAGAGT; } \\
\text { GTCGAGGTGCGGAGCTTG; } \\
\text { FAM-CTTGCTCAGCTTGTACTCAGGGC-BHQ1 }\end{array}$ & $127 \mathrm{bp}$ \\
\hline
\end{tabular}




\begin{tabular}{|c|c|c|c|c|}
\hline Test & $\begin{array}{l}\text { PCR composition and } \\
\text { conditions }\end{array}$ & \multicolumn{2}{|c|}{$\begin{array}{l}\text { Primers: forward; } \\
\text { reverse; } \\
\text { TaqMan probe / pyrosequencing primer (where applicable) }\end{array}$} & $\begin{array}{l}\text { PCR } \\
\text { fragment } \\
\text { length }\end{array}$ \\
\hline \multicolumn{5}{|c|}{ KRAS gene ${ }^{c}$} \\
\hline $\begin{array}{l}\text { HRM analysis } \\
\text { and } \\
\text { pyrosequencing } \\
\text { for KRAS } \\
\text { codons } 12-13\end{array}$ & $\begin{array}{l}20 \text { mkl volume reaction: } 1 \text {-x } \\
\text { GeneAmp PCR buffer I (Applied } \\
\text { Biosystems), } 1 \mathrm{U} \text { Taq M hot-start } \\
\text { DNA polymerase (AlkorBio), } \\
\text { 3.5 mM } \mathrm{MgCl}_{2}, 250 \mathrm{mkM} \text { dNTP, } \\
\text { 1-x EvaGreen (Biotium), } 200 \mathrm{nM} \\
\text { primers. } \\
\text { PCR program: } 95^{\circ} \mathrm{C} 10 \mathrm{~min}, \\
\text { followed by } 50 \mathrm{cycles}\left(95^{\circ} \mathrm{C} 15\right. \\
\text { sec, } 60^{\circ} \mathrm{C} 30 \mathrm{sec}, 72^{\circ} \mathrm{C} 30 \mathrm{sec} \text { ), } \\
\text { then melting from } 65^{\circ} \mathrm{C} \text { to } 95^{\circ} \mathrm{C} \text {. } \\
\text { Device: LightCycler } 96 \\
\text { instrument (Roche Life Science). }\end{array}$ & \multicolumn{2}{|c|}{$\begin{array}{l}\text { AATGACTGAATATAAACTTGTGG; } \\
\text { biotin-CAAGATTTACCTCTATTGTTGG; } \\
\text { TGTGGTAGTTGGAGC }\end{array}$} & 122 bp \\
\hline \multirow{10}{*}{$\begin{array}{l}\text { Real-time AS- } \\
\text { PCR for frequent } \\
\text { KRAS mutations } \\
\text { in codons } 12-13\end{array}$} & \multirow{10}{*}{$\begin{array}{l}20 \text { mkl volume reaction: } 1-x \\
\text { GeneAmp PCR buffer I (Applied } \\
\text { Biosystems), } 1 \mathrm{U} \text { Taq M hot-start } \\
\text { DNA polymerase (AlkorBio), } \\
2.0 \mathrm{mM} \text { MgCl} 2,250 \mathrm{mkM} \\
\text { dNTP, } 1 \text {-x SYBR Green I, } 150 \\
\text { nM primers. } \\
\text { PCR program: } 95^{\circ} \mathrm{C} 10 \mathrm{~min}, \\
\text { followed by } 50 \text { cycles }\left(95^{\circ} \mathrm{C} 15\right. \\
\text { sec, } 62^{\circ} \mathrm{C} 30 \mathrm{sec}, 72^{\circ} \mathrm{C} 30 \mathrm{sec} \text {, } \\
\text { then melting from } 65^{\circ} \mathrm{C} \text { to } 95^{\circ} \mathrm{C} \text {. } \\
\text { Device: CFX } 96(\mathrm{Bio}-\mathrm{Rad}) .\end{array}$} & $\begin{array}{l}\text { WT-specific } \\
\text { reaction }\end{array}$ & $\begin{array}{l}\text { CTTGTGGTAGTTGGAGCTGG; } \\
\text { TGTATCAAAGAATGGTCCTGC }\end{array}$ & 149 bp \\
\hline & & $\begin{array}{l}\text { G12D-specific } \\
\text { reaction }\end{array}$ & $\begin{array}{l}\text { CTTGTGGTAGTTGGAGCTGA; } \\
\text { TGTATCAAAGAATGGTCCTGC }\end{array}$ & 149 bp \\
\hline & & $\begin{array}{l}\text { G12V-specific } \\
\text { reaction }\end{array}$ & $\begin{array}{l}\text { CTTGTGGTAGTTGGAGCTGT; } \\
\text { TGTATCAAAGAATGGTCCTGC }\end{array}$ & 149 bp \\
\hline & & $\begin{array}{l}\text { G13D-specific } \\
\text { reaction }\end{array}$ & $\begin{array}{l}\text { GGTAGTTGGAGCTGGTGA; } \\
\text { TGTATCAAAGAATGGTCCTGC }\end{array}$ & 144 bp \\
\hline & & $\begin{array}{l}\text { G12C-specific } \\
\text { reaction }\end{array}$ & $\begin{array}{l}\text { ACTTGTGGTAGTTGGAGCTT; } \\
\text { TGTATCAAAGAATGGTCCTGC }\end{array}$ & $150 \mathrm{bp}$ \\
\hline & & $\begin{array}{l}\text { G12A-specific } \\
\text { reaction }\end{array}$ & $\begin{array}{l}\text { CTTGTGGTAGTTGGAGCTGC; } \\
\text { TGTATCAAAGAATGGTCCTGC }\end{array}$ & 149 bp \\
\hline & & $\begin{array}{l}\text { G12S-specific } \\
\text { reaction }\end{array}$ & $\begin{array}{l}\text { CTTGTGGTAGTTGGAGCTA; } \\
\text { TGTATCAAAGAATGGTCCTGC }\end{array}$ & 149 bp \\
\hline & & $\begin{array}{l}\text { G12R-specific } \\
\text { reaction }\end{array}$ & $\begin{array}{l}\text { CTTGTGGTAGTTGGAGCTC; } \\
\text { TGTATCAAAGAATGGTCCTGC }\end{array}$ & 149 bp \\
\hline & & $\begin{array}{l}\text { G13C-specific } \\
\text { reaction }\end{array}$ & $\begin{array}{l}\text { TTGTGGTAGTTGGAGCTGGTT; } \\
\text { TGTATCAAAGAATGGTCCTGC }\end{array}$ & 148 bp \\
\hline & & $\begin{array}{l}\text { G13R-specific } \\
\text { reaction }\end{array}$ & $\begin{array}{l}\text { GTGGTAGTTGGAGCTGGTGC; } \\
\text { TGTATCAAAGAATGGTCCTGC }\end{array}$ & 146 bp \\
\hline $\begin{array}{l}\text { HRM analysis } \\
\text { and } \\
\text { pyrosequencing } \\
\text { for KRAS } \\
\text { codons } 59-61^{\mathrm{d}}\end{array}$ & $\begin{array}{l}20 \text { mkl volume reaction: } 1 \text {-x } \\
\text { GeneAmp PCR buffer I (Applied } \\
\text { Biosystems), } 1 \mathrm{U} \text { Taq M hot-start } \\
\text { DNA polymerase (AlkorBio), } \\
2.5 \mathrm{mM} \mathrm{MgCl}_{2}, 250 \mathrm{mkM} \mathrm{dNTP} \\
1 \text {-x EvaGreen (Biotium), } 200 \mathrm{nM} \\
\text { forward primer, } 70 \mathrm{nM} \text { reverse } \\
\text { primer. } \\
\text { PCR program: } 95^{\circ} \mathrm{C} 10 \mathrm{~min}, \\
\text { followed by } 50 \text { cycles }\left(95^{\circ} \mathrm{C} 15\right. \\
\left.\text { sec, } 60^{\circ} \mathrm{C} 30 \text { sec, } 72^{\circ} \mathrm{C} 30 \mathrm{sec}\right), \\
\text { then melting from } 65^{\circ} \mathrm{C} \text { to } 95^{\circ} \mathrm{C} \text {. } \\
\text { Device: LightCycler } 96 \\
\text { instrument (Roche Life Science). }\end{array}$ & \multicolumn{2}{|c|}{$\begin{array}{l}\text { biotin-TGTAAAACGACGGCCAGTACCTGTCTCTTGGATATTCTC; } \\
\text { AGCGGATAACAATTTCACACAGGTACTGGTCCCTCATTGCAC; } \\
\text { GTCCCTCATTGCACTGT }\end{array}$} & 106 bp \\
\hline
\end{tabular}




\begin{tabular}{|c|c|c|c|c|}
\hline Test & $\begin{array}{l}\text { PCR composition and } \\
\text { conditions }\end{array}$ & \multicolumn{2}{|c|}{$\begin{array}{l}\text { Primers: forward; } \\
\text { reverse; } \\
\text { TaqMan probe / pyrosequencing primer (where applicable) }\end{array}$} & $\begin{array}{l}\text { PCR } \\
\text { fragment } \\
\text { length }\end{array}$ \\
\hline \multirow{9}{*}{$\begin{array}{l}\text { Real-time AS- } \\
\text { PCR for frequent } \\
\text { mutations in } \\
\text { codons } 59-61\end{array}$} & \multirow{9}{*}{$\begin{array}{l}20 \text { mkl volume reaction: } 1-\mathrm{x} \\
\text { GeneAmp PCR buffer I } \\
\text { (Applied Biosystems), } 1 \mathrm{U} \text { Taq } \\
\mathrm{M} \text { hot-start DNA polymerase } \\
\text { (AlkorBio), } 2.0 \mathrm{mM} \mathrm{MgCl} 2 \mathrm{in} \\
\text { total, } 250 \mathrm{mkM} \text { dNTP, } 1-\mathrm{x} \\
\text { SYBR Green I dye, } 130 \mathrm{nM} \\
\text { primers. } \\
\text { PCR program: } 95^{\circ} \mathrm{C} 10 \mathrm{~min}, \\
\text { followed by } 50 \mathrm{cycles}\left(95^{\circ} \mathrm{C} 15\right. \\
\text { sec, } 62^{\circ} \mathrm{C} 30 \mathrm{sec}, 72^{\circ} \mathrm{C} 30 \mathrm{sec} \text { ), } \\
\text { then melting from } 65^{\circ} \mathrm{C} \text { to } \\
95^{\circ} \mathrm{C} \text {. } \\
\text { Device: CFX } 96 \text { (Bio-Rad). }\end{array}$} & $\begin{array}{l}\text { WT-specific } \\
\text { reaction }\end{array}$ & $\begin{array}{l}\text { GACTGTGTTTCTCCCTTCTCA; } \\
\text { CTGTACTCCTCTTGACCTGC }\end{array}$ & $105 \mathrm{bp}$ \\
\hline & & $\begin{array}{l}\text { A59G-specific } \\
\text { reaction }\end{array}$ & $\begin{array}{l}\text { GACTGTGTTTCTCCCTTCTCA; } \\
\text { CACTGTACTCCTCTTGACCTC }\end{array}$ & $107 \mathrm{bp}$ \\
\hline & & $\begin{array}{l}\text { A59T-specific } \\
\text { reaction }\end{array}$ & $\begin{array}{l}\text { GACTGTGTTTCTCCCTTCTCA; } \\
\text { CTGTACTCCTCTTGACCTGT }\end{array}$ & $105 \mathrm{bp}$ \\
\hline & & $\begin{array}{l}\text { Q61H } \\
(\mathrm{CAA}>\mathrm{CAC})- \\
\text { specific reaction }\end{array}$ & $\begin{array}{l}\text { GACTGTGTTTCTCCCTTCTCA; } \\
\text { TCATTGCACTGTACTCCTCG }\end{array}$ & $113 \mathrm{bp}$ \\
\hline & & $\begin{array}{l}\text { Q61H } \\
(\mathrm{CAA}>\mathrm{CAT})- \\
\text { specific reaction }\end{array}$ & $\begin{array}{l}\text { GACTGTGTTTCTCCCTTCTCA; } \\
\text { CTCATTGCACTGTACTCCTCA }\end{array}$ & $114 \mathrm{bp}$ \\
\hline & & $\begin{array}{l}\text { Q61L-specific } \\
\text { reaction }\end{array}$ & $\begin{array}{l}\text { GACTGTGTTTCTCCCTTCTCA; } \\
\text { TCATTGCACTGTACTCCTCTA }\end{array}$ & $113 \mathrm{bp}$ \\
\hline & & $\begin{array}{l}\text { Q61R-specific } \\
\text { reaction }\end{array}$ & $\begin{array}{l}\text { GACTGTGTTTCTCCCTTCTCA; } \\
\text { TCATTGCACTGTACTCCTCTC }\end{array}$ & $113 \mathrm{bp}$ \\
\hline & & $\begin{array}{l}\text { Q61K-specific } \\
\text { reaction }\end{array}$ & $\begin{array}{l}\text { GACTGTGTTTCTCCCTTCTCA; } \\
\text { TCATTGCACTGTACTCCTCTTT }\end{array}$ & $113 \mathrm{bp}$ \\
\hline & & $\begin{array}{l}\text { Q61E-specific } \\
\text { reaction }\end{array}$ & $\begin{array}{l}\text { GACTGTGTTTCTCCCTTCTCA; } \\
\text { TCATTGCACTGTACTCCTCTTC }\end{array}$ & $113 \mathrm{bp}$ \\
\hline $\begin{array}{l}\text { HRM analysis } \\
\text { and } \\
\text { pyrosequencing } \\
\text { for KRAS } \\
\text { codon } 146\end{array}$ & $\begin{array}{l}20 \text { mkl volume reaction: } 1-\mathrm{x} \\
\text { GeneAmp PCR buffer I } \\
\text { (Applied Biosystems), } 1 \mathrm{U} \text { Taq } \\
\text { M hot-start DNA polymerase } \\
\text { (AlkorBio), } 3.5 \mathrm{mM} \mathrm{MgCl}_{2}, \\
250 \mathrm{mkM} \text { dNTP, } 1 \text {-x EvaGreen } \\
\text { (Biotium), } 200 \mathrm{nM} \text { primers. } \\
\text { PCR program: } 95^{\circ} \mathrm{C} 10 \mathrm{~min}, \\
\text { followed by } 50 \text { cycles }\left(95^{\circ} \mathrm{C} 15\right. \\
\text { sec, } 60^{\circ} \mathrm{C} 30 \mathrm{sec}, 72^{\circ} \mathrm{C} 30 \mathrm{sec} \text { ), } \\
\text { then melting from } 65^{\circ} \mathrm{C} \text { to } \\
95^{\circ} \mathrm{C} \text {. } \\
\text { Device: LightCycler } 96 \\
\text { instrument (Roche Life } \\
\text { Science). }\end{array}$ & \multicolumn{2}{|c|}{$\begin{array}{l}\text { biotin-GTAGACACAAAACAGGCTCAG; } \\
\text { TGTATTTATTTCAGTGTTACTTAC; } \\
\text { TGTTACTTACCTGTCTTG }\end{array}$} & $102 \mathrm{bp}$ \\
\hline \multirow{4}{*}{$\begin{array}{l}\text { Real-time AS- } \\
\text { PCR for } \\
\text { frequently } \\
\text { occurring } \\
\text { mutations in } \\
\text { codon } 146\end{array}$} & \multirow{4}{*}{$\begin{array}{l}20 \text { mkl volume reaction: } 1 \text {-x } \\
\text { GeneAmp PCR buffer I } \\
\text { (Applied Biosystems), } 1 \mathrm{U} \text { Taq } \\
\mathrm{M} \text { hot-start DNA polymerase } \\
\text { (AlkorBio), } 2.5 \mathrm{mM} \mathrm{MgCl}_{2} \text {, } \\
250 \mathrm{mkM} \text { dNTP, } 1-\mathrm{x} \mathrm{SYBR} \\
\text { Green I, } 175 \mathrm{nM} \text { primers. } \\
\text { PCR program: } 95^{\circ} \mathrm{C} 10 \mathrm{~min}, \\
\text { followed by } 50 \text { cycles }\left(95^{\circ} \mathrm{C} 15\right. \\
\text { sec, } 62^{\circ} \mathrm{C} 30 \mathrm{sec}, 72^{\circ} \mathrm{C} 30 \mathrm{sec} \text { ), } \\
\text { then melting from } 65^{\circ} \mathrm{C} \text { to } \\
95^{\circ} \mathrm{C} \text {. } \\
\text { Device: } \mathrm{CFX} 96(\mathrm{Bio}-\mathrm{Rad}) .\end{array}$} & $\begin{array}{l}\text { WT-specific } \\
\text { reaction }\end{array}$ & $\begin{array}{l}\text { AGATGTACCTATGGTCCTAGTA; } \\
\text { ACTTACCTGTCTTGTCTTTGC }\end{array}$ & $136 \mathrm{bp}$ \\
\hline & & $\begin{array}{l}\text { A146T-specific } \\
\text { reaction }\end{array}$ & $\begin{array}{l}\text { AGATGTACCTATGGTCCTAGTA; } \\
\text { ACTTACCTGTCTTGTCTTTGT }\end{array}$ & $136 \mathrm{bp}$ \\
\hline & & $\begin{array}{l}\text { A146P-specific } \\
\text { reaction }\end{array}$ & $\begin{array}{l}\text { AGATGTACCTATGGTCCTAGTA; } \\
\text { ACTTACCTGTCTTGTCTTTGG }\end{array}$ & $136 \mathrm{bp}$ \\
\hline & & $\begin{array}{l}\text { A146V-specific } \\
\text { reaction }\end{array}$ & $\begin{array}{l}\text { AGATGTACCTATGGTCCTAGTA; } \\
\text { GTTACTTACCTGTCTTGTCTTTA }\end{array}$ & 139 bp \\
\hline
\end{tabular}




\begin{tabular}{|c|c|c|c|c|}
\hline Test & $\begin{array}{l}\text { PCR composition and } \\
\text { conditions }\end{array}$ & \multicolumn{2}{|c|}{$\begin{array}{l}\text { Primers: forward; } \\
\text { reverse; } \\
\text { TaqMan probe / pyrosequencing primer (where applicable) }\end{array}$} & $\begin{array}{l}\text { PCR } \\
\text { fragment } \\
\text { length }\end{array}$ \\
\hline \multicolumn{5}{|c|}{ BRAF gene } \\
\hline $\begin{array}{l}\text { HRM analysis } \\
\text { and } \\
\text { pyrosequencing } \\
\text { for BRAF exon } \\
15\end{array}$ & $\begin{array}{l}20 \text { mkl volume reaction: } 1 \text {-x } \\
\text { GeneAmp PCR buffer I } \\
\text { (Applied Biosystems), } 1 \mathrm{U} \text { Taq } \\
\text { M hot-start DNA polymerase } \\
\text { (AlkorBio), } 3.5 \mathrm{mM} \mathrm{MgCl}_{2}, \\
250 \mathrm{mkM} \text { dNTP, } 1 \text {-x EvaGreen } \\
\text { (Biotium), } 200 \mathrm{nM} \text { primers. } \\
\text { PCR program: } 95^{\circ} \mathrm{C} 10 \mathrm{~min}, \\
\text { followed by } 50 \text { cycles }\left(95^{\circ} \mathrm{C} 15\right. \\
\text { sec, } 60^{\circ} \mathrm{C} 30 \text { sec, } 72^{\circ} \mathrm{C} 30 \mathrm{sec} \text { ), } \\
\text { then melting from } 65^{\circ} \mathrm{C} \text { to } \\
95^{\circ} \mathrm{C} \text {. } \\
\text { Device: LightCycler } 96 \\
\text { instrument (Roche Life } \\
\text { Science). }\end{array}$ & \multicolumn{2}{|c|}{$\begin{array}{l}\text { CCTTTACTTACTACACCTCAG; } \\
\text { biotin-CACAAAATGGATGCAGACAACT; } \\
\text { GACCTCACAGTAAAAATAG }\end{array}$} & $136 \mathrm{bp}$ \\
\hline \multirow{2}{*}{$\begin{array}{l}\text { Real-time AS- } \\
\text { PCR for V600E } \\
\text { mutation }\end{array}$} & \multirow{2}{*}{$\begin{array}{l}20 \text { mkl volume reaction: } 1 \text {-x } \\
\text { GeneAmp PCR buffer I } \\
\text { (Applied Biosystems), } 1 \mathrm{U} \text { Taq } \\
\text { M hot-start DNA polymerase } \\
\text { (AlkorBio), } 2.5 \mathrm{mM} \mathrm{MgCl}_{2}, \\
250 \mathrm{mkM} \text { dNTP, } 1 \text {-x SYBR } \\
\text { Green I, } 130 \mathrm{nM} \text { primers. } \\
\text { PCR program: } 95^{\circ} \mathrm{C} 10 \mathrm{~min}, \\
\text { followed by } 50 \text { cycles }\left(95^{\circ} \mathrm{C} 15\right. \\
\text { sec, } 62^{\circ} \mathrm{C} 30 \mathrm{sec}, 72^{\circ} \mathrm{C} 30 \mathrm{sec} \text { ) } \\
\text { and melting from } 65^{\circ} \mathrm{C} \text { to } 95^{\circ} \mathrm{C} \text {. } \\
\text { Device: CFX } 96(\mathrm{Bio}-\mathrm{Rad}) .\end{array}$} & $\begin{array}{l}\text { WT-specific } \\
\text { reaction }\end{array}$ & $\begin{array}{l}\text { GGTGATTTTGGTCTAGCTACAGT; } \\
\text { ATAGCCTCAATTCTTACCATCC }\end{array}$ & $101 \mathrm{bp}$ \\
\hline & & $\begin{array}{l}\text { V600E-specific } \\
\text { reaction }\end{array}$ & $\begin{array}{l}\text { GGTGATTTTGGTCTAGCTACAGA; } \\
\text { ATAGCCTCAATTCTTACCATCC }\end{array}$ & $101 \mathrm{bp}$ \\
\hline
\end{tabular}

Abbreviations: PCR - polymerase chain reaction; AS-PCR - allele-specific PCR; qPCR - quantitative real-time PCR; HRM high resolution melting; dNTP - deoxynucleotide; WT - wild-type.

${ }^{a}$ Primer sequences and reaction conditions were taken from [Mitiushkina et al., Cancer Cytopathol 2013; 121(7): 370-376]. Allelespecific primers for EGFR L858R mutation detection were modified to increase the reaction specificity.

${ }^{b}$ This method was described in detail in [Iyevleva et al., Cancer Lett 2015; 362(1): 116-121].

${ }^{c}$ Analysis of mutations in KRAS codons 12-13, 61, 146 and BRAF exon 15 was previously described in [Yanus et al., Med Oncol 2013; 30(3): 686].

${ }^{\mathrm{d}}$ Primers used for this reaction contain additional 5'-sequences to increase PCR fragment length; that was done to improve results of direct Sanger sequencing. 


\section{Examples of mutation tests}

\section{EGFR gene}

a) Test for deletions and insertions in exon 19 (PCR, followed by polyacrylamide gel electrophoresis)

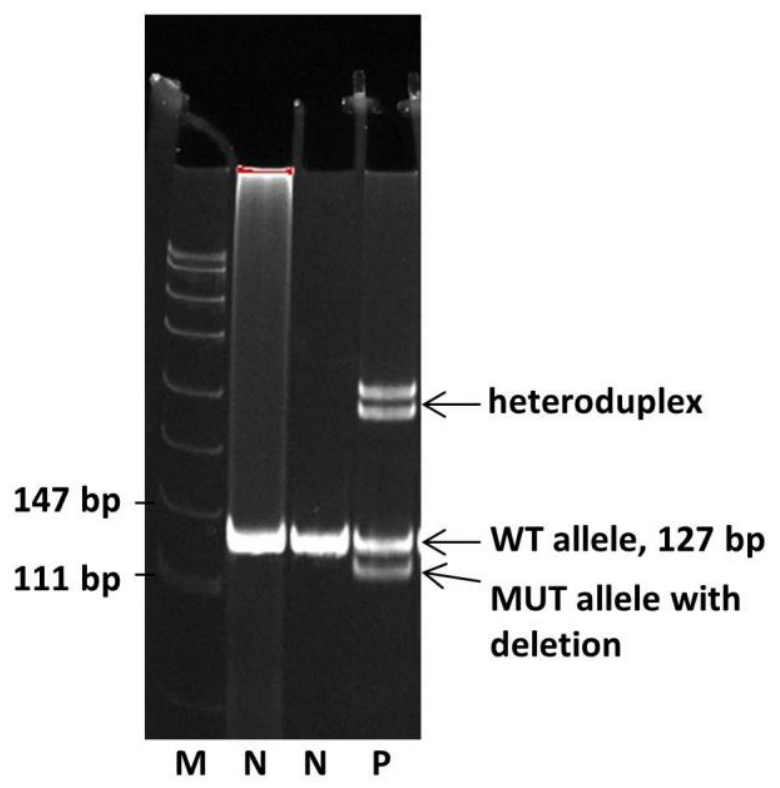

Abbreviations: $\mathrm{P}$ - positive result; $\mathrm{N}$ - negative result; $\mathrm{M}$ - molecular weight marker; WT - wild-type; MUT - mutant

b) Test for L858R point mutation (allele-specific PCR)
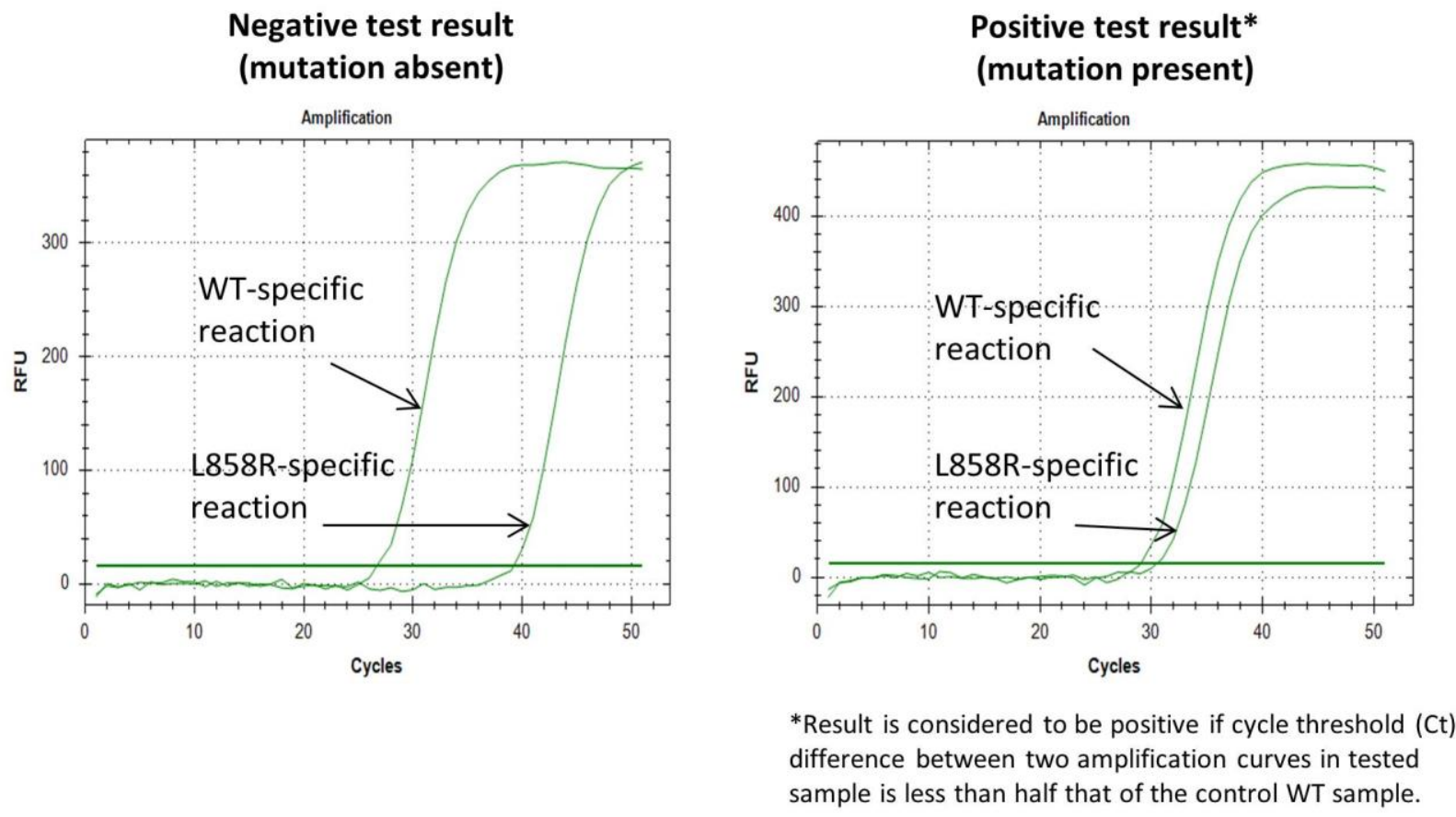

Abbreviations: WT - wild-type 


\section{ALK gene}

a) Test for unbalanced 3'/5' ALK expression*
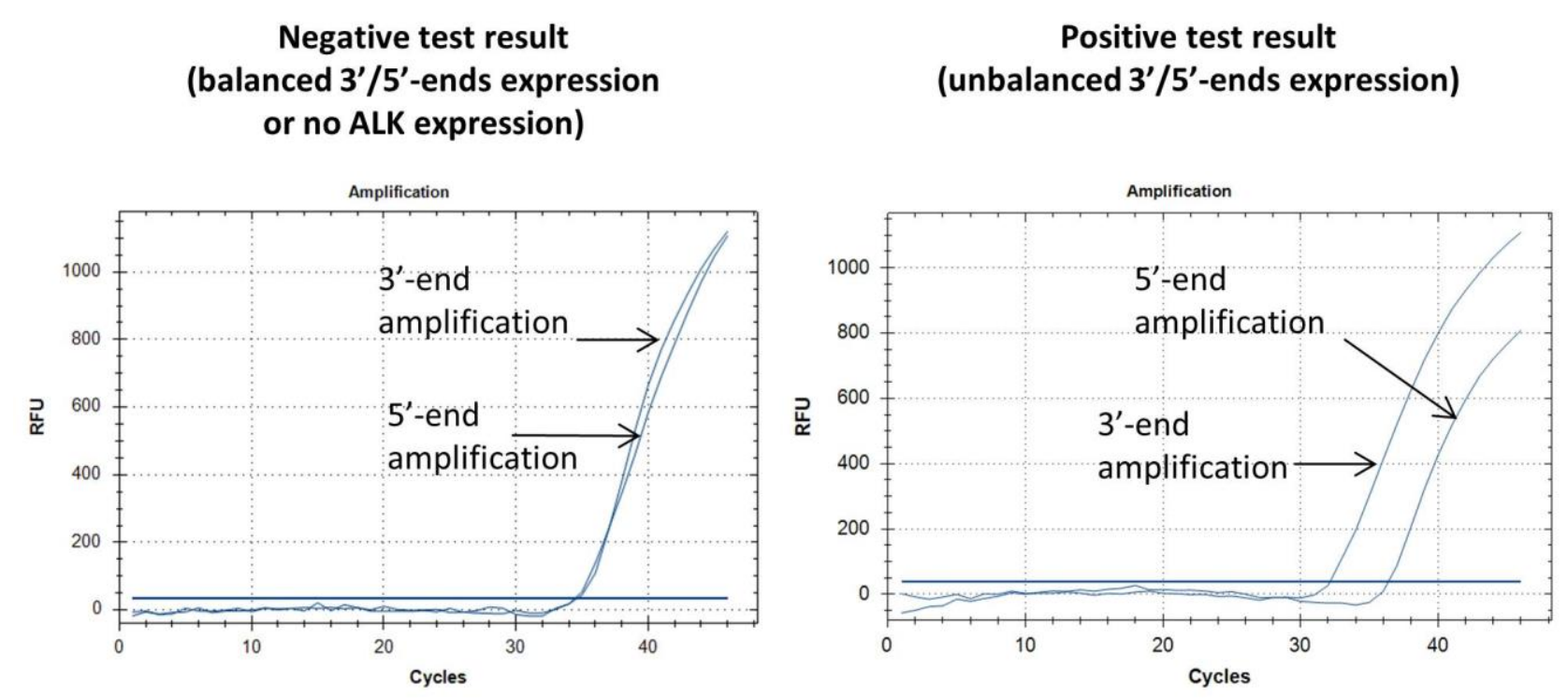

*This test is based on a method originally suggested by Wang R. et al [Clin Cancer Res. 2012; 18(17):47254732] and is described in detail in Iyevleva A.G. et al. [Cancer Lett 2015; 362(1): 116-121].

\section{b) PCR tests for specific ALK gene rearrangements (applied to cases with unbalanced 3'/5'-ends ALK expression)}

Negative test result (sample tested negative for all known ALK fusions)

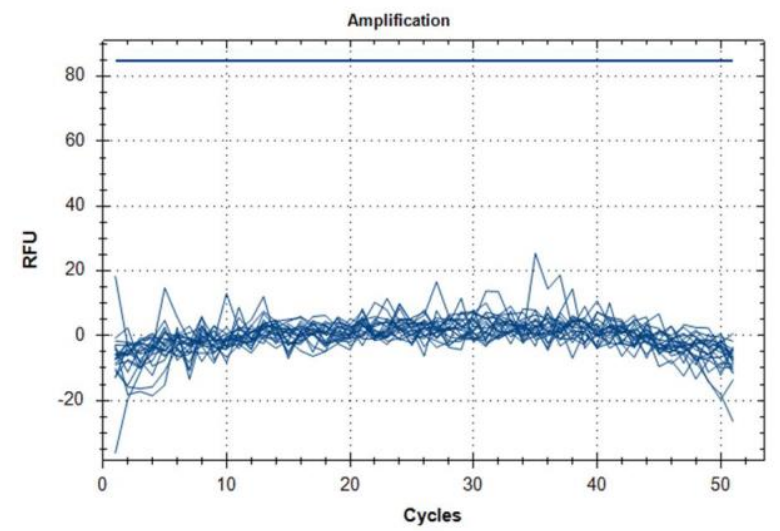

\section{Positive test result}

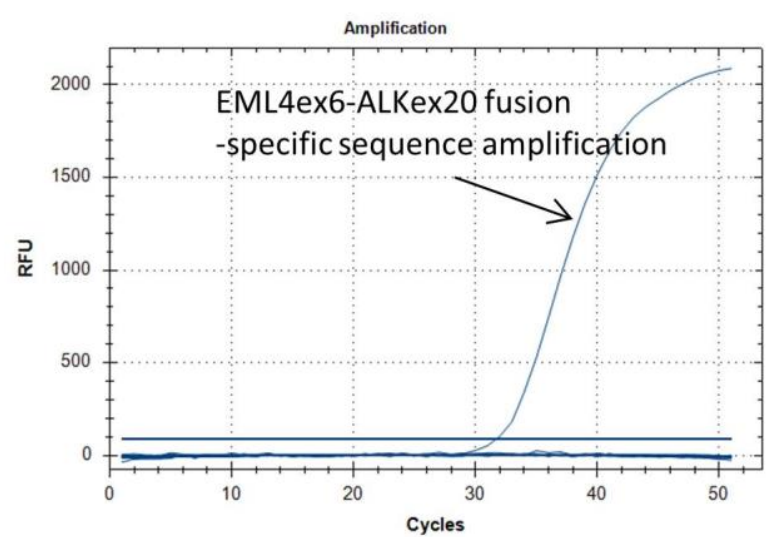


KRAS gene

a) HRM analysis for exon 2 (KRAS codons 12-13)
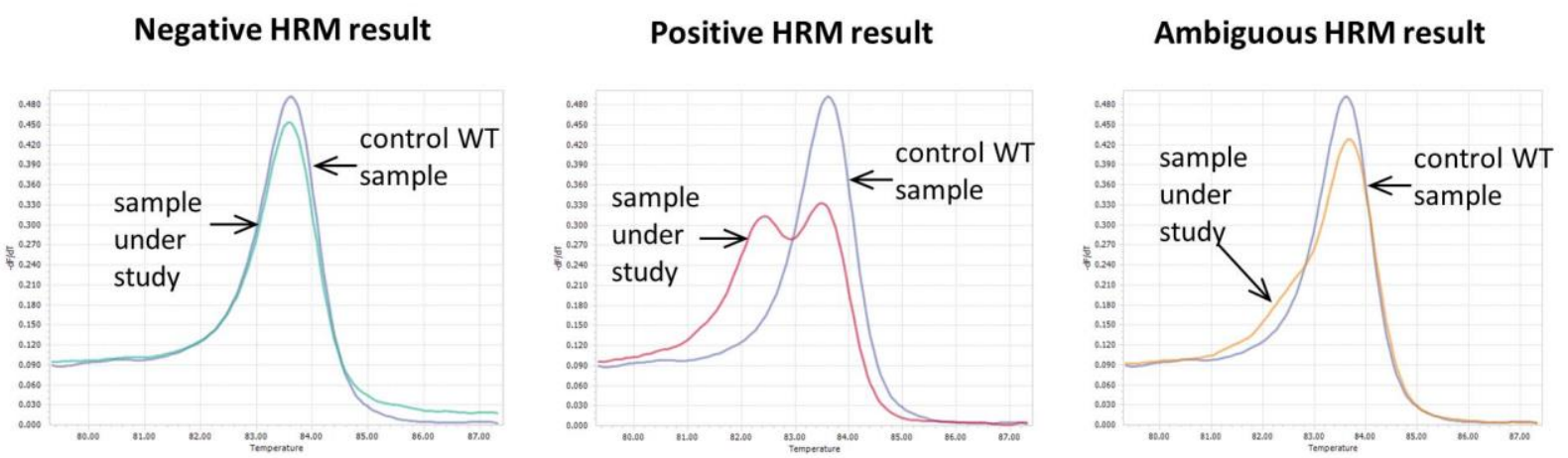

Abbreviations: HRM - high resolution melting curve analysis; WT - wild-type

b) Allele-specific PCR (AS-PCR) test for nine frequently occurring mutations in codons 12 and 13 (applied to cases with positive or ambiguous HRM test results).

Negative test result

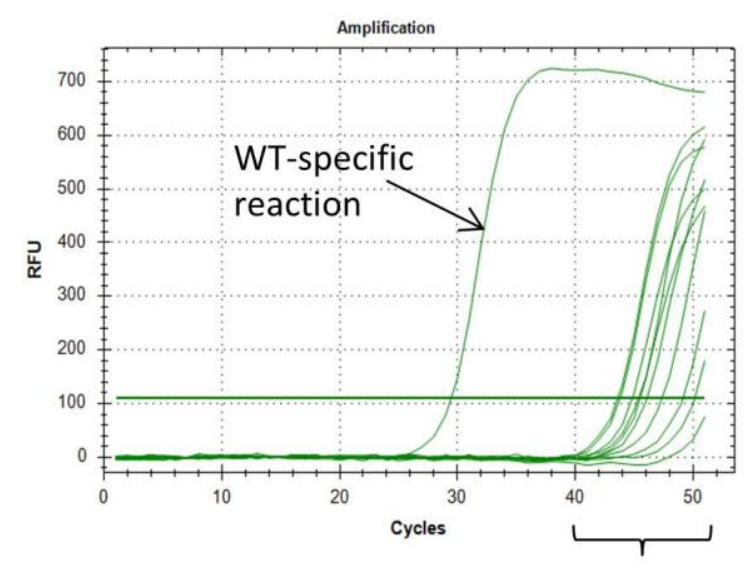

MUT-specific reactions
Positive test result

(KRAS G12V)

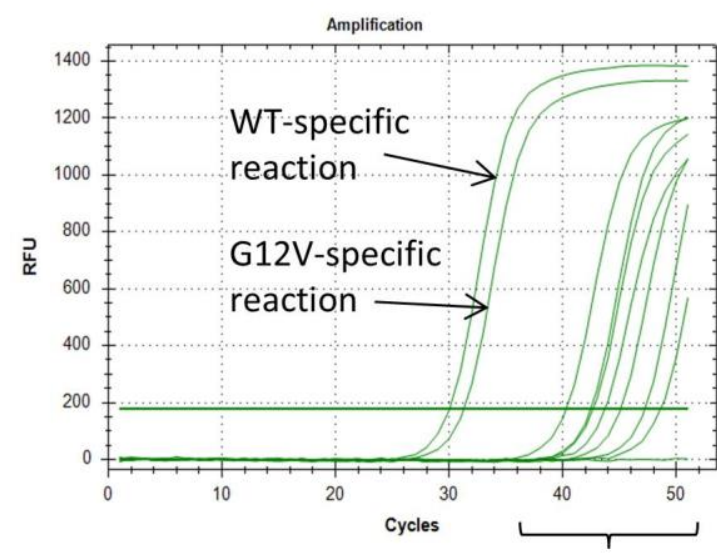

other MUT-specific reactions

Abbreviations: WT - wild-type; MUT - mutant 
c) Pyrosequencing or Sanger sequencing of the DNA fragment containing KRAS codons 12-13 (applied to cases with positive or ambiguous HRM test results) if:

- DNA quality or quantity was insufficient for AS-PCR

- AS-PCR results were negative for all tested mutations

- AS-PCR result was inconclusive.

Negative pyrosequencing result

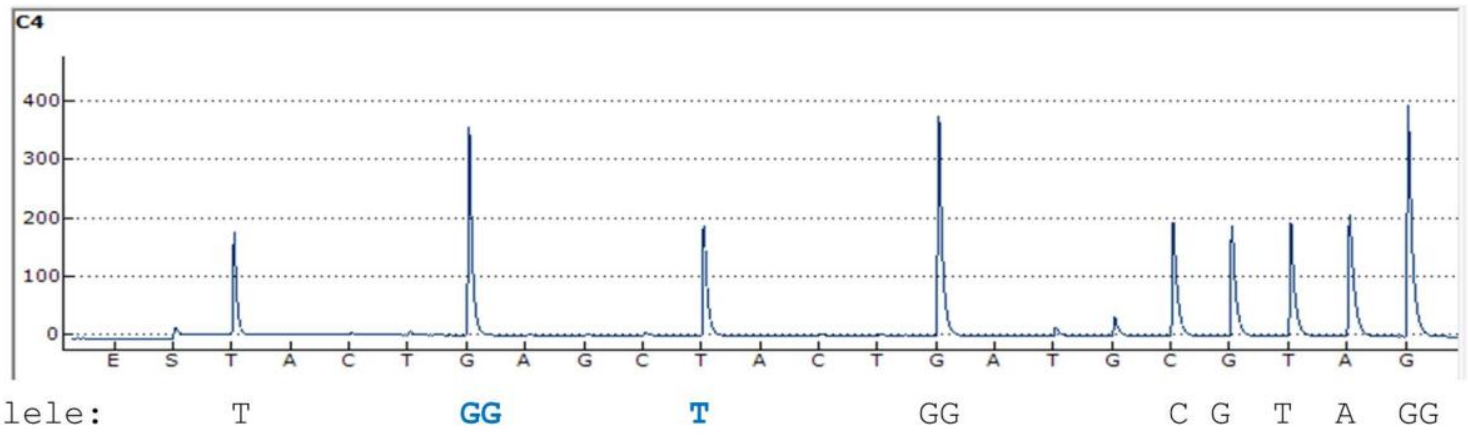

WT allele: T

Positive pyrosequencing result

(codon 12 GGT > GAT, KRAS G12D mutation)

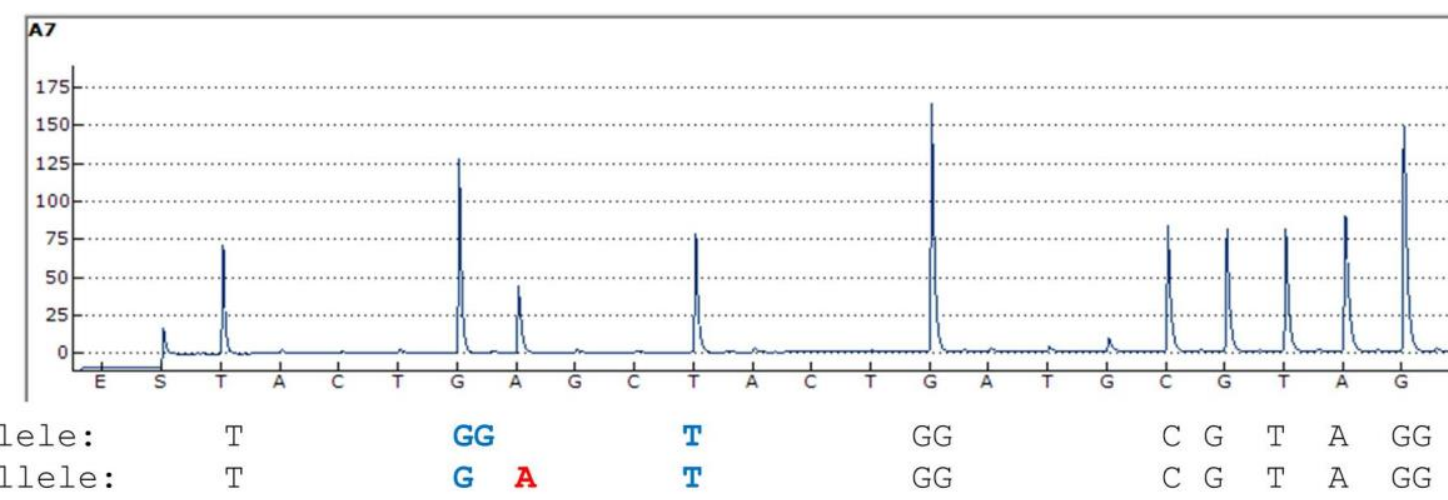

Abbreviations: WT - wild-type; MUT - mutant 

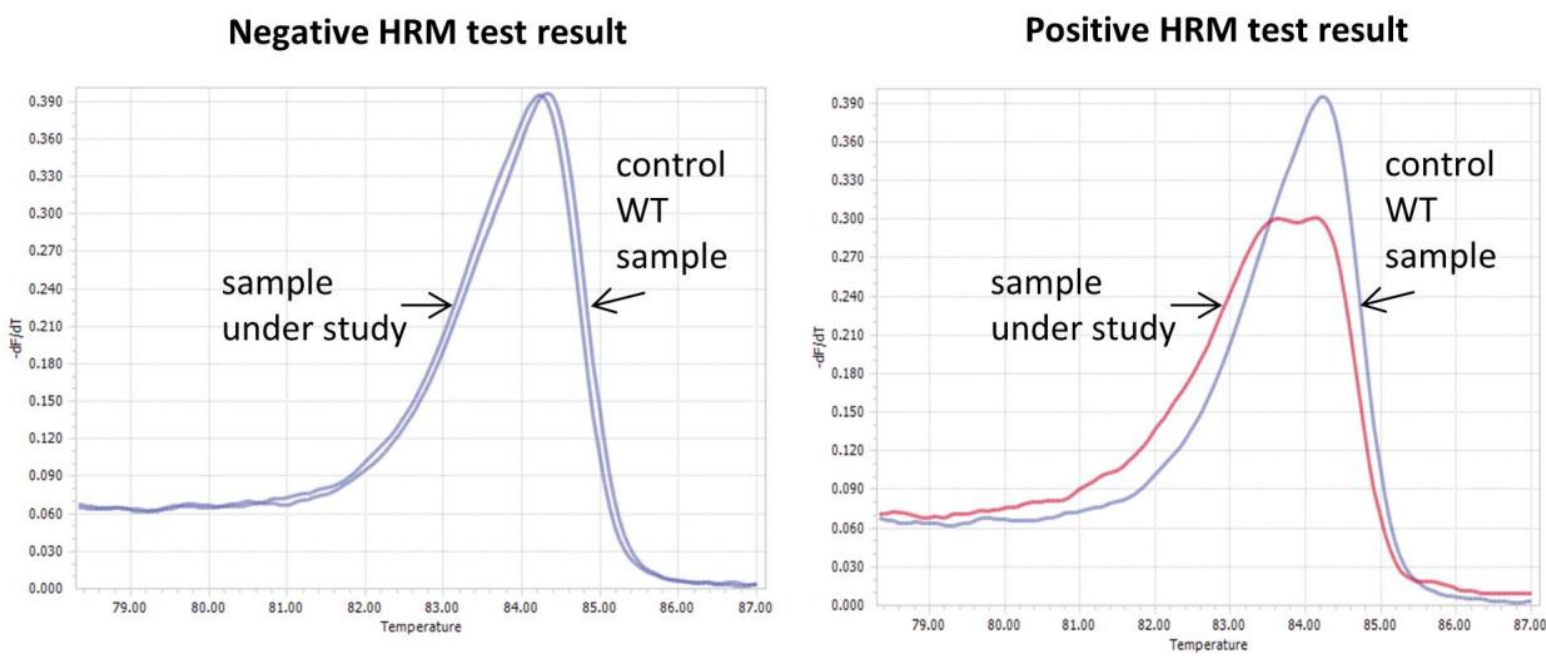

Abbreviations: HRM - high resolution melting curve analysis; WT - wild-type

e) Allele-specific PCR (AS-PCR) test for eight frequently occurring mutations in KRAS codons 59-61 (applied to cases with positive or ambiguous HRM test results).

Negative test result

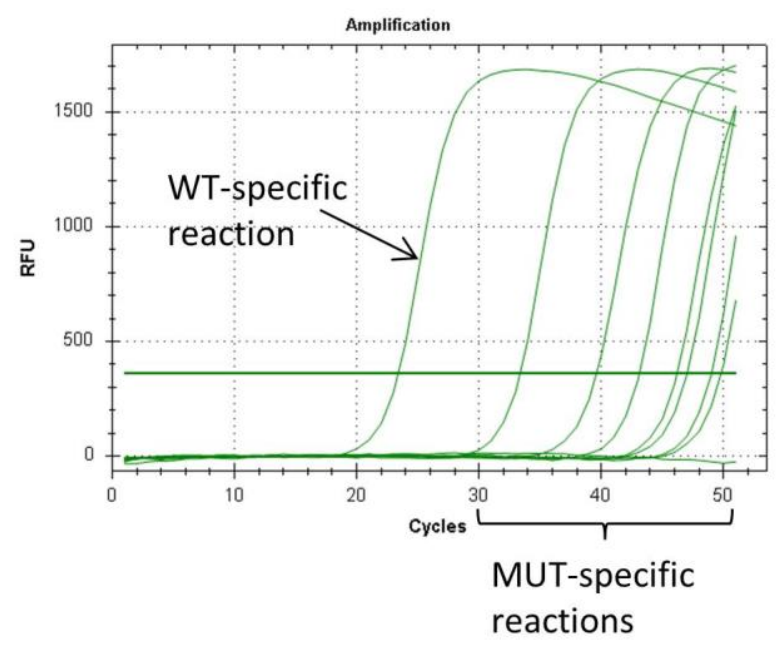

Positive test result

(KRAS Q61H)

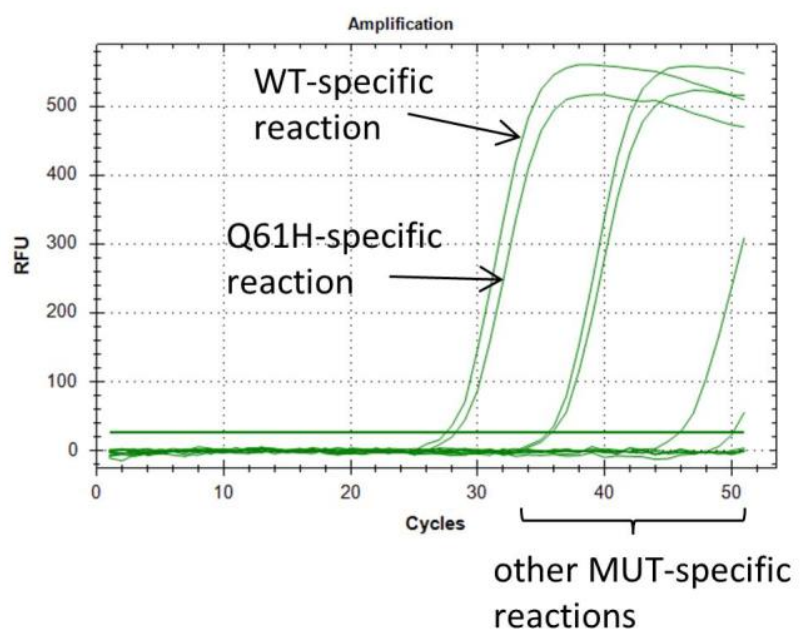

Abbreviations: WT - wild-type; MUT - mutant 
f) Pyrosequencing or Sanger sequencing of the DNA fragment containing KRAS codons 59-61 (applied to cases with positive or ambiguous HRM test results) if:

- DNA quality or quantity was insufficient for AS-PCR

- AS-PCR results were negative for all tested mutations

- AS-PCR result was inconclusive.

\section{Negative pyrosequencing result}

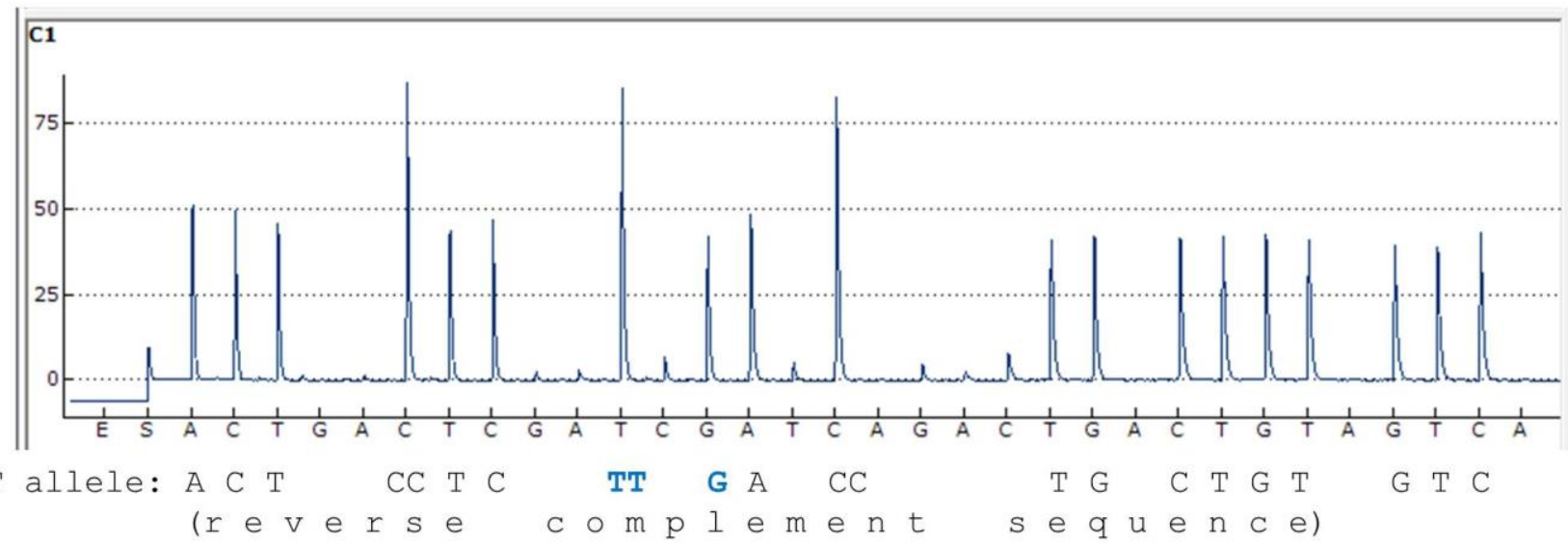

\section{Positive pyrosequencing result}

(codon 61 CAA > CAC [reverse complement TTG > GTG], KRAS Q61H mutation)

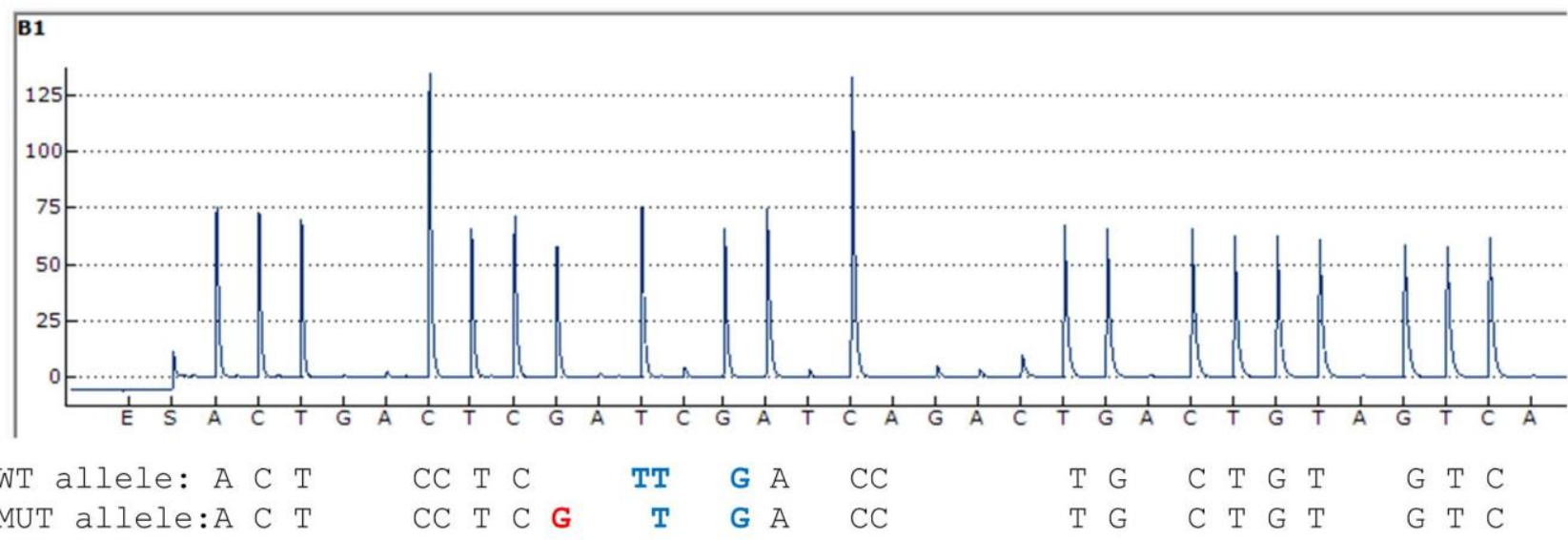

Abbreviations: WT - wild-type; MUT - mutant 
Negative HRM test result

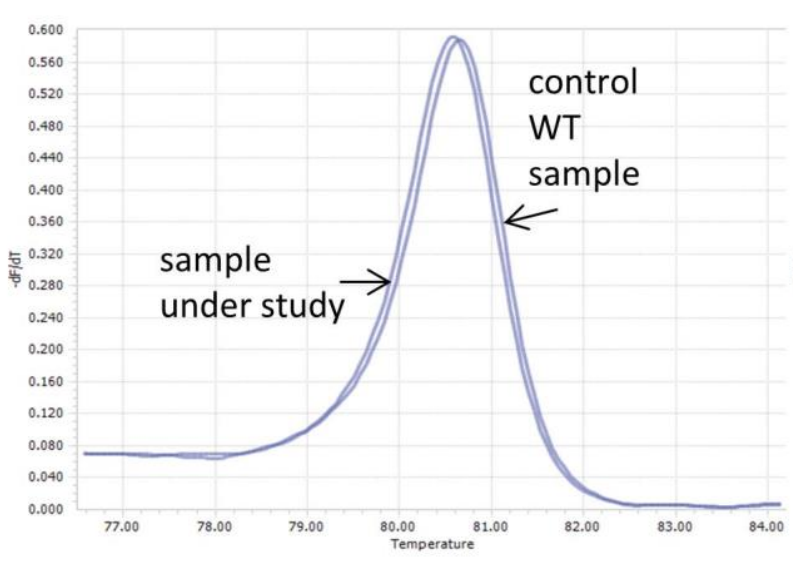

Positive HRM test result

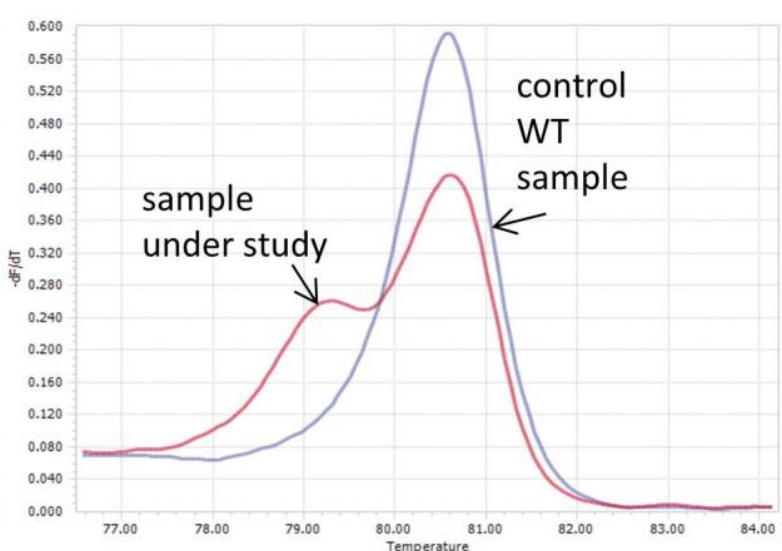

Abbreviations: HRM - high resolution melting curve analysis; WT - wild-type

h) Allele-specific PCR (AS-PCR) test for three frequently occurring mutations in KRAS codon 146 (applied to cases with positive or ambiguous HRM test results)
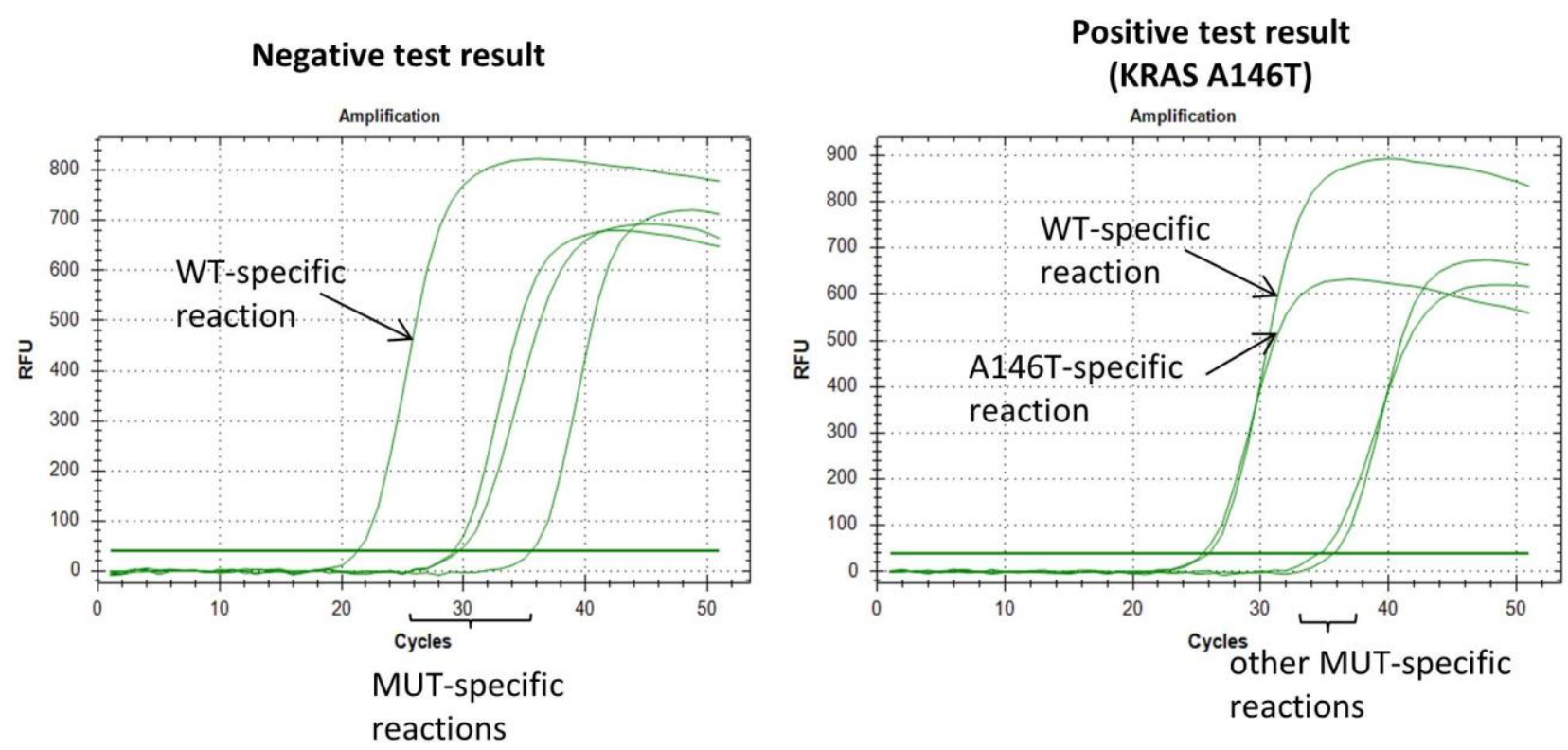

Abbreviations: WT - wild-type; MUT - mutant 
i) Pyrosequencing or Sanger sequencing of the DNA fragment containing KRAS codon 146 (applied in cases with positive or ambiguous HRM test results) if:

- DNA quality or quantity was insufficient for AS-PCR

- AS-PCR results were negative for all tested mutations

- AS-PCR result was inconclusive.

Negative pyrosequencing result
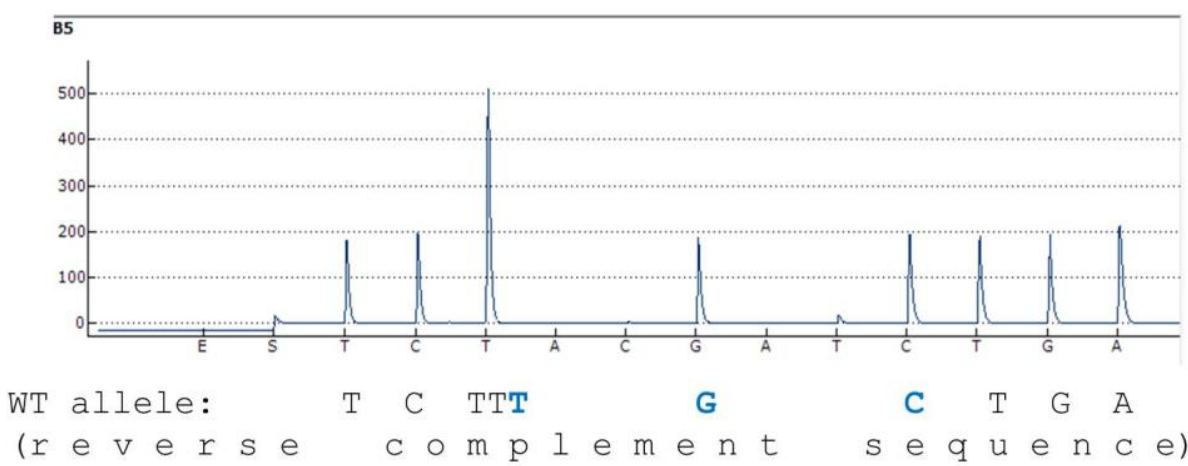

Positive pyrosequencing result

(codon 146 GCA > GTA [reverse complement TGC > TAC], KRAS A146V mutation)

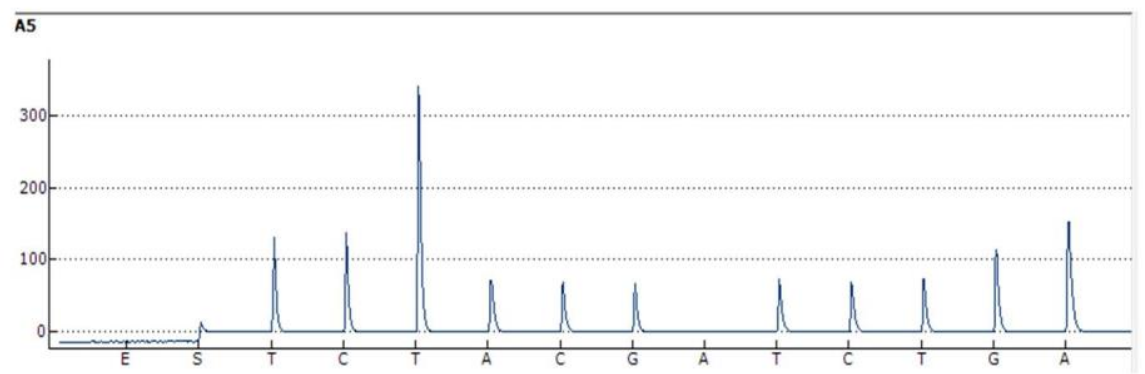

WT allele: T C TTT

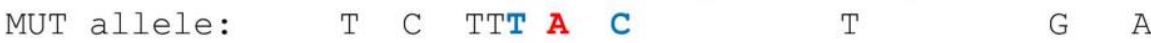

Abbreviations: WT - wild-type; MUT - mutant 
BRAF gene

a) HRM analysis for BRAF exon 15 fragment (codon 600)

Negative HRM test result

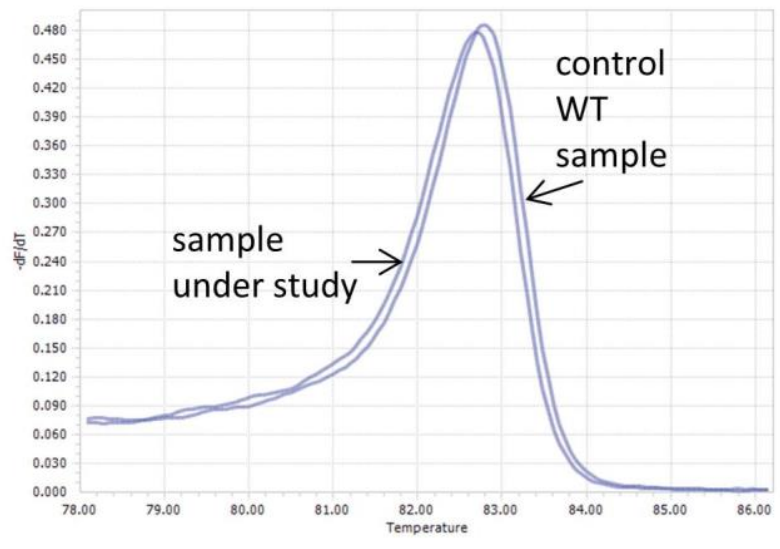

Positive HRM test result

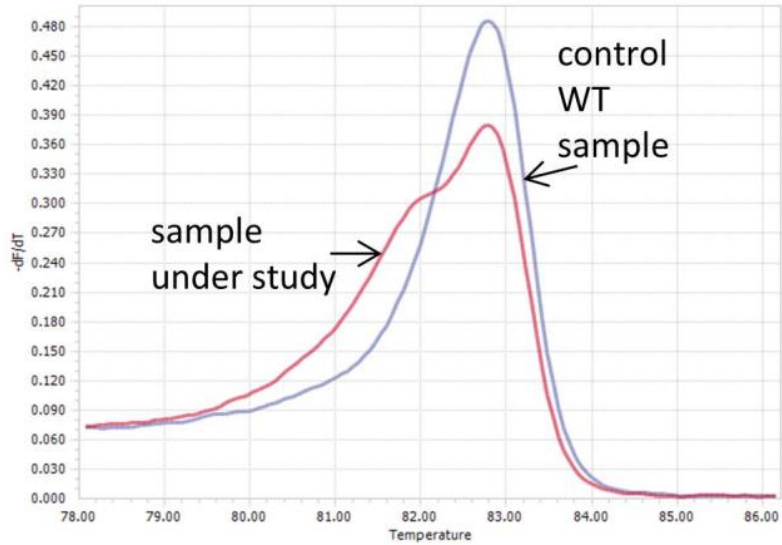

Abbreviations: HRM - high resolution melting curve analysis; WT - wild-type

b) Allele-specific PCR (AS-PCR) test for BRAFV600E mutation (applied to cases with positive or ambiguous HRM test results).

Negative test result (mutation absent)

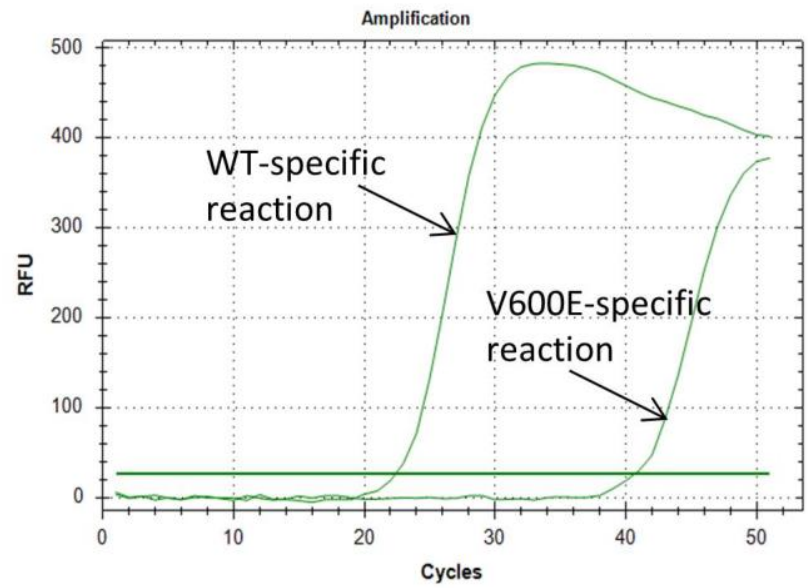

Positive test result (mutation present)

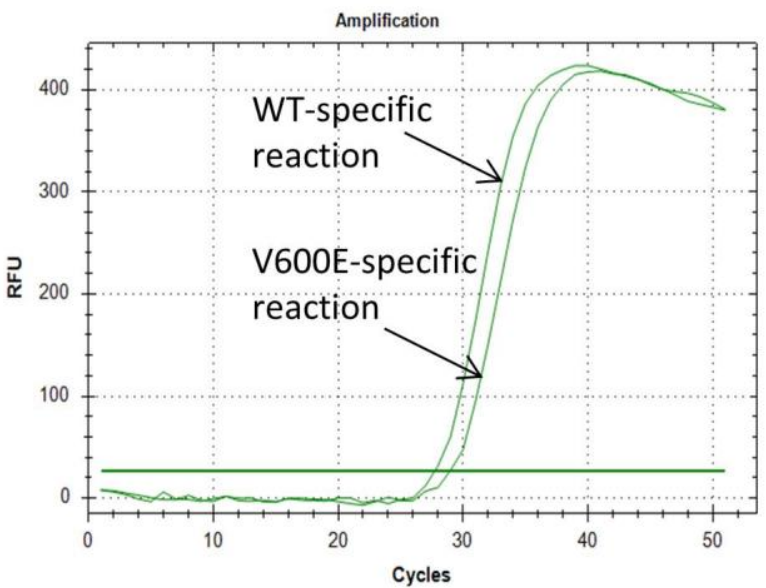

Abbreviations: WT - wild-type 
c) Pyrosequencing or Sanger sequencing of the DNA fragment containing BRAF codon 600 (applied to cases with positive or ambiguous HRM test results) if:

- DNA quality or quantity was insufficient for AS-PCR

- AS-PCR results were negative for all tested mutations

- AS-PCR result was inconclusive.

\section{Negative pyrosequencing result}

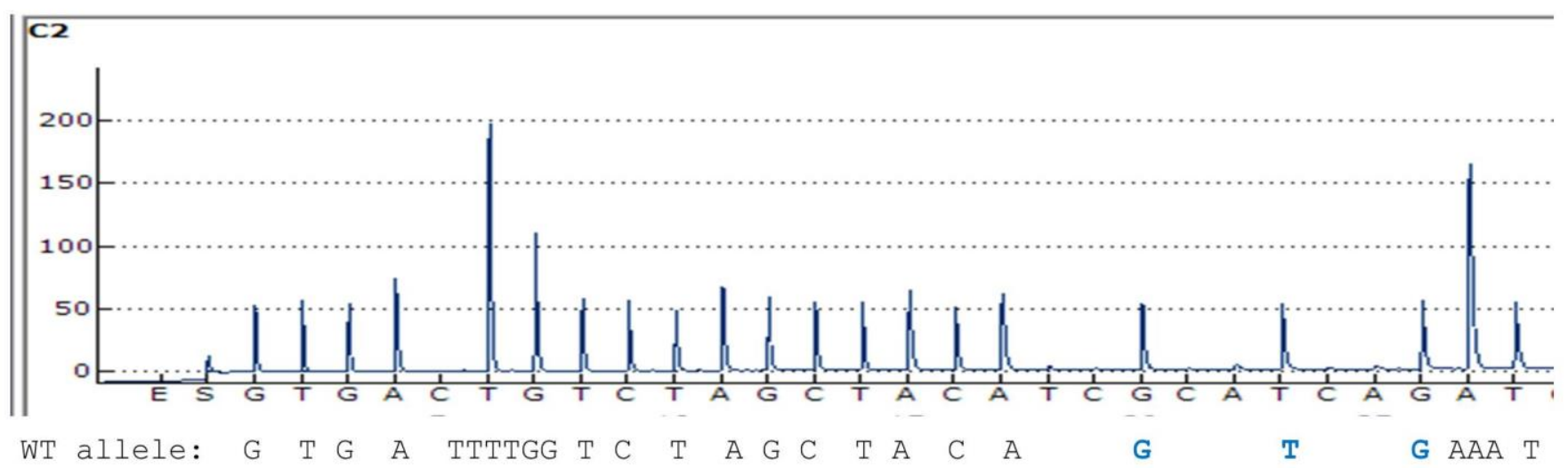

WT allele: $G$ T G A TTTTGG T C T A G C T A $\mathrm{C}$ A

Positive pyrosequencing result

(codon 600 GTG > GAG, BRAF V600E mutation)

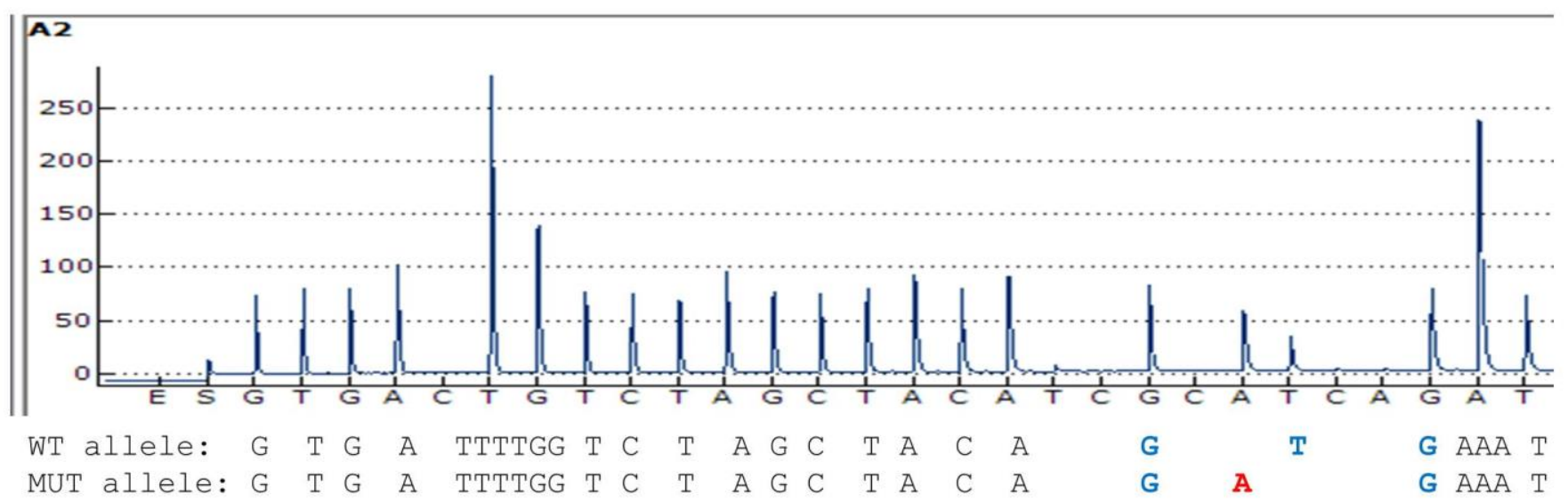

Abbreviations: WT - wild-type; MUT - mutant 


\section{PCR-based detection of EGFR, ALK, KRAS and BRAF mutations in Russian patients with lung adenocarcinoma: a single-center experience}

N. V. MITIUSHKINA ${ }^{1, *}$, M. M. KHOLMATOV ${ }^{1,2}$, A. R. VENINA ${ }^{1}$, V. I. TIURIN ${ }^{1}$, G. A. YANUS ${ }^{1,2}$, T. N. SOKOLOVA ${ }^{1}$, O. S. YATSUK ${ }^{1}$, O. A. ZAITSEVA ${ }^{1}$, A. O. IVANTSOV ${ }^{1,2}$, E. SH. KULIGINA ${ }^{1}$, A. V. TOGO ${ }^{1,2}$, E. N. IMYANITOV ${ }^{1,2,3,4}$

\section{Supplemental Material}

Suppl. Table 1. Gender difference in the distribution of EGFR, ALK, KRAS and BRAF genotypes.

\begin{tabular}{|c|c|c|c|c|c|c|c|c|c|c|c|c|}
\hline & \multicolumn{3}{|c|}{ Ever-smokers } & \multicolumn{3}{|c|}{ Never-smokers } & \multicolumn{3}{|c|}{ Smoking status unknown } & \multicolumn{3}{|c|}{ All } \\
\hline & $\mathbf{M}$ & $\mathbf{F}$ & p-value ${ }^{\mathbf{a}}$ & M & $\mathbf{F}$ & p-value & M & $\mathbf{F}$ & p-value & M & $\mathbf{F}$ & p-value \\
\hline $\begin{array}{l}\text { EGFR mutations: L858R } \\
\text { or ex19del }\end{array}$ & $\begin{array}{l}36 / 557 \\
(6.5 \%)\end{array}$ & $\begin{array}{c}9 / 56 \\
(16.1 \%)\end{array}$ & 0.033 & $\begin{array}{l}18 / 129 \\
(14.0 \%)\end{array}$ & $\begin{array}{l}196 / 461 \\
(42.5 \%)\end{array}$ & $4.8 \times 10^{-6}$ & $\begin{array}{l}44 / 684 \\
(6.4 \%)\end{array}$ & $\begin{array}{l}167 / 445 \\
(37.5 \%)\end{array}$ & $<2.2 \times 10^{-16}$ & $\begin{array}{c}98 / 1370 \\
(7.2 \%)\end{array}$ & $\begin{array}{l}372 / 962 \\
(38.7 \%)\end{array}$ & $<2.2 \times 10^{-16}$ \\
\hline $\begin{array}{l}\text { ALK translocations } \\
\text { (EGFR-negative cases) }\end{array}$ & $\begin{array}{l}6 / 521 \\
(1.2 \%)\end{array}$ & $0 / 47$ & 1.000 & $\begin{array}{c}6 / 111 \\
(5.4 \%)\end{array}$ & $\begin{array}{l}26 / 265 \\
(9.8 \%)\end{array}$ & 0.227 & $\begin{array}{l}23 / 640 \\
(3.6 \%)\end{array}$ & $\begin{array}{l}34 / 278 \\
(12.2 \%)\end{array}$ & $1.3 \times 10^{-5}$ & $\begin{array}{c}35 / 1272 \\
(2.8 \%)\end{array}$ & $\begin{array}{l}60 / 590 \\
(10.2 \%)\end{array}$ & $1.1 \times 10^{-10}$ \\
\hline $\begin{array}{l}\text { KRAS mutations (EGFR/ } \\
\text { ALK-negative cases) }\end{array}$ & $\begin{array}{l}139 / 439 \\
(31.7 \%)\end{array}$ & $\begin{array}{c}12 / 44 \\
(27.3 \%)\end{array}$ & 0.744 & $\begin{array}{c}26 / 94 \\
(27.7 \%)\end{array}$ & $\begin{array}{l}45 / 209 \\
(21.5 \%)\end{array}$ & 0.398 & $\begin{array}{l}135 / 411 \\
(32.8 \%)\end{array}$ & $\begin{array}{l}35 / 171 \\
(20.5 \%)\end{array}$ & 0.025 & $\begin{array}{l}300 / 944 \\
(31.8 \%)\end{array}$ & $\begin{array}{l}92 / 424 \\
(21.7 \%)\end{array}$ & 0.00013 \\
\hline $\begin{array}{l}\text { KRAS G12C mutations } \\
\text { (EGFR/ALK-negative } \\
\text { cases) }\end{array}$ & $\begin{array}{l}56 / 439 \\
(12.8 \%)\end{array}$ & $\begin{array}{c}8 / 44 \\
(18.2 \%)\end{array}$ & 0.367 & $\begin{array}{c}6 / 94 \\
(6.4 \%)\end{array}$ & $\begin{array}{l}1 / 209 \\
(0.5 \%)\end{array}$ & 0.005 & $\begin{array}{l}49 / 411 \\
(11.9 \%)\end{array}$ & $\begin{array}{c}8 / 171 \\
(4.7 \%)\end{array}$ & 0.013 & $\begin{array}{l}111 / 944 \\
(11.8 \%)\end{array}$ & $\begin{array}{l}17 / 424 \\
(4.0 \%)\end{array}$ & $1.8 \times 10^{-6}$ \\
\hline $\begin{array}{l}\text { KRAS G12D mutations } \\
\text { (EGFR/ALK-negative } \\
\text { cases) }\end{array}$ & $\begin{array}{l}18 / 439 \\
(4.1 \%)\end{array}$ & $\begin{array}{c}2 / 44 \\
(4.5 \%)\end{array}$ & 0.703 & $\begin{array}{c}8 / 94 \\
(8.5 \%)\end{array}$ & $\begin{array}{l}18 / 209 \\
(8.6 \%)\end{array}$ & 1.000 & $\begin{array}{l}21 / 411 \\
(5.1 \%)\end{array}$ & $\begin{array}{l}12 / 171 \\
(7.0 \%)\end{array}$ & 0.434 & $\begin{array}{l}47 / 944 \\
(5.0 \%)\end{array}$ & $\begin{array}{l}32 / 424 \\
(7.5 \%)\end{array}$ & 0.078 \\
\hline $\begin{array}{l}\text { BRAF V600E mutations } \\
\text { (EGFR/ALK/KRAS- } \\
\text { negative cases) }\end{array}$ & $\begin{array}{l}4 / 266 \\
(1.5 \%)\end{array}$ & $\begin{array}{c}1 / 28 \\
(3.6 \%)\end{array}$ & 0.402 & $0 / 63$ & $\begin{array}{l}8 / 132 \\
(6.1 \%)\end{array}$ & 0.060 & $\begin{array}{c}1 / 27 \\
(3.7 \%)\end{array}$ & $0 / 27$ & 1.000 & $\begin{array}{l}5 / 356 \\
(1.4 \%)\end{array}$ & $\begin{array}{c}9 / 187 \\
(4.8 \%)\end{array}$ & 0.023 \\
\hline
\end{tabular}

M - males; F - females; ${ }^{a}$ Fisher's exact test p-value

Suppl. Table 2. Median age of patients with particular genetic abnormalities in their tumors vs. patients with no such abnormalities (Mann-Whitney $\mathrm{U}$-test $\mathbf{p}$ is provided).

\begin{tabular}{|c|c|c|c|c|}
\hline & Ever-smokers & Never-smokers & Smoking status unknown & All \\
\hline EGFR mutations: L858R or ex19del & $\begin{array}{l}60 \text { vs. } 61 \\
(p=0.378)\end{array}$ & $\begin{array}{c}65 \text { vs. } 62 \\
(p=0.0002)\end{array}$ & $\begin{array}{c}64 \text { vs. } 61 \\
\left(p=6.5 \times 10^{-6}\right)\end{array}$ & $\begin{array}{c}64 \text { vs. } 61 \\
\left(p=2.1 \times 10^{-11}\right)\end{array}$ \\
\hline $\begin{array}{l}\text { ALK translocations } \\
\text { (EGFR-negative cases) }\end{array}$ & $\begin{array}{l}58.5 \text { vs. } 61 \\
(p=0.697)\end{array}$ & $\begin{array}{l}56 \text { vs. } 63 \\
(\mathrm{p}=\mathbf{0 . 0 0 5})\end{array}$ & $\begin{array}{c}54 \text { vs. } 61 \\
\left(p=4.2 \cdot \mathbf{1 0}^{-7}\right)\end{array}$ & $\begin{array}{c}55 \text { vs. } 61 \\
\left(\mathrm{p}=\mathbf{2 . 5} \times \mathbf{1 0}^{-8}\right)\end{array}$ \\
\hline $\begin{array}{l}\text { KRAS mutations } \\
\text { (EGFR/ALK-negative cases) }\end{array}$ & $\begin{array}{l}59 \text { vs. } 61 \\
(p=0.058)\end{array}$ & $\begin{array}{l}63 \text { vs. } 63 \\
(p=0.764)\end{array}$ & $\begin{array}{l}60.5 \text { vs. } 62 \\
(p=0.146)\end{array}$ & $\begin{array}{c}61 \text { vs. } 62 \\
(p=\mathbf{0 . 0 1 3})\end{array}$ \\
\hline $\begin{array}{l}\text { KRAS G12C mutations } \\
\text { (EGFR/ALK-negative cases) }\end{array}$ & $\begin{array}{l}59 \text { vs. } 61 \\
(p=0.137)\end{array}$ & $\begin{array}{l}69 \text { vs. } 63 \\
(\mathrm{p}=\mathbf{0 . 0 3 5})\end{array}$ & $\begin{array}{l}60 \text { vs. } 62 \\
(p=0.063)\end{array}$ & $\begin{array}{l}60 \text { vs. } 62 \\
(p=\mathbf{0 . 0 4 1})\end{array}$ \\
\hline $\begin{array}{l}\text { KRAS G12D mutations } \\
\text { (EGFR/ALK-negative cases) }\end{array}$ & $\begin{array}{l}57 \text { vs. } 61 \\
(\mathrm{p}=\mathbf{0 . 0 1 9})\end{array}$ & $\begin{array}{l}60.5 \text { vs. } 63 \\
(p=0.065)\end{array}$ & $\begin{array}{l}62 \text { vs. } 61 \\
(p=0.527)\end{array}$ & $\begin{array}{l}60 \text { vs. } 61 \\
(p=0.088\end{array}$ \\
\hline $\begin{array}{l}\text { KRAS G12V mutations } \\
\text { (EGFR/ALK-negative cases) }\end{array}$ & $\begin{array}{l}59 \text { vs. } 61 \\
(\mathrm{p}=0.334)\end{array}$ & $\begin{array}{l}63.5 \text { vs. } 63 \\
(p=0.814)\end{array}$ & $\begin{array}{l}63.5 \text { vs. } 61 \\
(p=0.676)\end{array}$ & $\begin{array}{l}62 \text { vs. } 61 \\
(p=0.669)\end{array}$ \\
\hline $\begin{array}{l}\text { KRAS G12A mutations } \\
\text { (EGFR/ALK-negative cases) }\end{array}$ & $\begin{array}{l}64.5 \text { vs. } 60 \\
(p=0.238)\end{array}$ & $\begin{array}{l}65 \text { vs. } 63 \\
(p=0.417)\end{array}$ & $\begin{array}{l}63 \text { vs. } 61 \\
(p=0.535)\end{array}$ & $\begin{array}{l}65 \text { vs. } 61 \\
(\mathrm{p}=0.119)\end{array}$ \\
\hline $\begin{array}{l}\text { BRAF V600E mutations } \\
\text { (EGFR/ALK/KRAS-negative cases) }\end{array}$ & $\begin{array}{l}73 \text { vs. } 61 \\
(\mathrm{p}=0.190)\end{array}$ & $\begin{array}{l}70.5 \text { vs. } 63 \\
(\mathrm{p}=\mathbf{0 . 0 1 1})\end{array}$ & - & $\begin{array}{l}72.5 \text { vs. } 63 \\
(p=0.009)\end{array}$ \\
\hline
\end{tabular}

